\title{
Invited review: Compost-bedded pack barns for dairy cows
}

\author{
L. Leso, ${ }^{1} \odot$ M. Barbari, ${ }^{1 *} \odot$ M. A. Lopes, ${ }^{2}$ F. A. Damasceno,,${ }^{3}$ P. Galama, ${ }^{4} \odot$ J. L. Taraba, ${ }^{5}$ and A. Kuipers ${ }^{4} \odot$ \\ ${ }^{1}$ Department of Agriculture, Food, Environment and Forestry, University of Florence, IT50145 Firenze, Italy \\ ${ }^{2}$ Department of Veterinary Medicine, Federal University of Lavras, Campus UFLA-DMV, 37200-000, Lavras, MG, Brazil \\ ${ }^{3}$ Department of Engineering, Federal University of Lavras, Campus UFLA-DMV, 37200-000, Lavras, MG, Brazil \\ ${ }^{4}$ Livestock Research, Wageningen University and Research Centre, 8219 PH Lelystad, the Netherlands \\ ${ }^{5}$ Department of Biosystems and Agricultural Engineering, University of Kentucky, Lexington 40546
}

\begin{abstract}
Compost-bedded pack barns (CBP) are receiving increasing attention as a housing system for dairy cows that has potential to improve animal welfare. This article reviews current scientific knowledge about CBP with the aim of providing a comprehensive tool for producers and researchers using this housing system. In CBP, cows are provided with an open bedded pack area rather than the individual stalls and concrete alleys found in freestall systems. The bedded pack, a mixture of organic bedding and cattle excreta, is cultivated frequently (1-3 times per day) to incorporate fresh manure and air into the pack, thus promoting an aerobic composting process. To function well, CBP generally require a large area per cow. Optimal animal densities over the bedded area range from 7.4 to more than $15 \mathrm{~m}^{2} /$ cow depending on several factors, including climate, bedding, pack management, and cow characteristics. Studies have indicated that CBP, compared with conventional systems such as freestall barns, have the potential to improve the welfare of dairy cows. In particular, the main reported benefits include improved comfort during resting, better foot and leg health, and more natural animal behavior. Research has also indicated that adequate udder health can be achieved in CBP. However, because the bedded pack has been shown to contain high bacterial concentrations, proper management is essential to maintain adequate cow cleanliness and reduce the risk of mastitis. Controlling pack moisture is consistently indicated as the most important issue with CBP. Especially under cold and humid weather conditions, large amounts of bedding may be necessary to keep the pack adequately dry and comfortable for the cows. Nevertheless, the improvements in cow health may offset the higher costs of bedding.
\end{abstract}

Received April 26, 2019.

Accepted October 21, 2019.

*Corresponding author: matteo.barbari@unifi.it
Key words: dairy cow, compost-bedded pack barn, housing system, animal welfare

\section{INTRODUCTION}

Housing system can affect dairy cow welfare and performance and has a major influence on the ecological footprint and consumer perception of dairy farming. After the shift from tiestalls to loose housing, many different systems were developed. Although tiestall barns remain popular in some countries, the most widespread solutions for housing dairy cattle are straw yards (SY) and freestall barns (FS). In recent decades, FS have become established as the standard housing solution for dairy cows (Bewley et al., 2017). Because FS housing is based on the concept of keeping manure and urine separated from the surfaces where cows lie, this system allows an adequate level of cow hygiene to be maintained with a relatively low amount of bedding. However, in recent years, research has demonstrated that FS housing may compromise animal welfare and produce large amounts of liquid manure, which is known to contribute to emission of greenhouse gases (Petersen, 2018). Moreover, consumer concerns about the conditions of dairy cows in intensive systems have fostered interest in alternative housing solutions. Compost-bedded pack barns (CBP) are a relatively new housing system that, compared with FS, appears to improve cow comfort and minimize the risks traditionally associated with conventional bedded-pack barns such as SY. In this review, current knowledge on CBP is described with the aim of providing a comprehensive tool for producers and researchers using this system.

\section{AN ALTERNATIVE TO FS AND SY}

Freestall facilities are designed to provide a comfortable lying area for cows while simultaneously minimizing stall soiling by forcing cows to defecate and urinate in the alley outside of the stalls (Tucker et al., 2005). The stall size and hardware configuration must be set up by considering these 2 issues. Changes in stall design 
that improve cow comfort (e.g., providing larger stalls) usually come at the expense of cow cleanliness because cows are more likely to deposit manure within the stall (Bernardi et al., 2009; Fregonesi et al., 2009).

The lying surface in the stall and the bedding material can also affect cow comfort and hygiene in FS. Stalls can be either deep bedded or provided with synthetic mattresses. A wide range of materials can be used as bedding. The most common are sand, straw, sawdust, and recycled manure solids. Deep-bedded stalls generally provide a good comfort level, but they are labor intensive and require a relatively large amount of bedding material to maintain adequate hygienic conditions (Bewley et al., 2001). Synthetic mattresses were developed to reduce labor and bedding needs, but in many situations their use decreases lying comfort and increases hock lesions and lameness (Cook et al., 2004; Fulwider et al., 2007).

In recent years, several solutions have been developed to improve cow comfort in FS; however, the level of animal welfare in FS remains a matter of concern. Recent research commissioned by the European Commission (EFSA, 2009) indicated that the housing system is a major factor influencing animal welfare and that FS housing increases health-related risks, especially regarding leg injuries and locomotion. Lameness is largely recognized as one of the most important problems in modern dairy farms (Kester et al., 2014). Compromised claw health is a source of suffering for cows (Webster, 1995) because the disorder is usually long term and painful (Alban, 1995). In FS, the mean prevalence of lameness has been reported to be 13 to $55 \%$ (von Keyserlingk et al., 2012; Cook et al., 2016; Jewell et al., 2019). High lameness rates have given rise to growing concern about the conditions of cows in intensive farms (Kester et al., 2014).

In FS, manure and urine are deposited on the bare floor of the feed alley or in the alleys between cubicles. To avoid manure buildup on these surfaces, manure scrapers, washing systems, or slatted floors must be used. Regardless of the cleaning system, the main material used for flooring is concrete because it is durable, easily cleaned, and reasonably priced (Albright, 1995). Nevertheless, a concrete floor is hard and may be slippery, especially if it is not adequately grooved, and thus poses some challenges in terms of animal welfare and behavior.

In FS, concrete flooring is a major cause of claw disorders, especially when it is not adequately clean (Somers et al., 2005; Dippel et al., 2009; Telezhenko et al., 2009; Kester et al., 2014). Somers et al. (2003) found that in FS, $80 \%$ of cows exposed to concrete flooring have claw disorders at the clinical or subclinical level, and many cows have 2 diseases simultaneously. Covering the floor with rubber mats is a common solution to improve its physical characteristics and promote claw health (Vanegas et al., 2006; Fjeldaas et al., 2011; Eicher et al., 2013). However, rubber mats are expensive and, owing to their smooth surface, may decrease claw wear, thus resulting in claw overgrowth (Platz et al., 2007). Another problem associated with rubber flooring is the increased number of cows resting in the alleys, a behavior especially likely when the comfort of the resting area is inadequate (Platz et al., 2008). This behavior results in cow soiling, especially of the udder, and may increase the risk of infections such as mastitis.

Stall characteristics can also affect claw health indirectly. Uncomfortable stalls may modify the normal behavior of cows, thus decreasing lying time (Norring et al., 2008; Fregonesi et al., 2009; Gomez and Cook, 2010) and consequently increasing the risk of lesions and infections because the cows spend more time standing (or walking) on concrete (Fregonesi et al., 2007; Fulwider et al., 2007; Kester et al., 2014). Furthermore, behavioral modifications induced by inadequate housing adversely affect both productive and reproductive performance. Because lying time is positively associated with rumination, low comfort in resting areas may decrease milk production (Schirmann et al., 2012). On slippery floors, cows may feel unsafe and may not display normal behavior (Telezhenko and Bergsten, 2005; Frankena et al., 2009). Limited estrus behavior and reduced activity have been observed in cows housed on concrete floors, thus making heat detection more difficult and impairing fertility (López-Gatius et al., 2005; López-Gatius, 2012).

In conventional bedded-pack barns, including SY, cows are provided with an open pack resting area rather than individual stalls. The SY housing system is believed to provide better comfort than FS. In a recent review article, Kester et al. (2014) reported that the presence of hock lesions is strongly associated with time spent lying on abrasive surfaces, prolonged high local pressure or friction of the hock on hard surfaces, and collisions of the hock with cubicle fittings. The prevalence of hock lesions is positively correlated with the lameness rate (Haskell et al., 2006; Kester et al., 2014). In SY, the soft bedded surface on which cows lie, stand, and walk results in less hoof damage and lameness than the surfaces in FS (Somers et al., 2003; Haskell et al., 2006; Frankena et al., 2009).

Cows housed in SY also exhibit different behavior than do cows in FS. Fregonesi et al. (2009) found that when offered a choice, cows spend more time in open packs than in equivalent FS. Cows also spend more time lying and standing with all hooves in open packs than in stalls. Furthermore, when provided access to an open area, cows spend less time standing outside of 
the lying area and perching with the front hooves in the lying area, both of which are behaviors associated with increased risk of lameness. Studies on cows' time budgets have shown that cows in SY have longer lying times, ruminating times, and synchronization of lying behavior than those in FS (Fregonesi and Leaver, 2001).

However, SY may hinder cows' welfare through increasing the risk of IMI because maintaining adequate cow cleanliness can be a major issue in SY. Cows in SY have been found to be dirtier than those in FS (Fregonesi and Leaver, 2001) and thus to have poorer udder health. In fact, Fregonesi and Leaver (2001) found that both SCC and incidence of clinical mastitis are significantly higher in SY than in FS. Peeler et al. (2000) reported that housing lactating cows in SY is a significant risk factor associated with the incidence of clinical mastitis.

Freestall barns and SY have been widely used for more than 50 yr. From an animal welfare standpoint, the main advantages of FS compared with SY appear to be cow cleanliness and reduced mastitis. However, FS housing poses several challenges in terms of claw health and cow behavior as well as manure quality. Animal welfare has recently become one of the most important issues facing the dairy sector because consumer demand for animal-friendly systems has risen and is likely to continue to increase. As a result, an interest in alternative housing systems has been fostered.

\section{WHAT ARE CBP?}

Compost-bedded pack barns are a relatively new loose housing system for dairy cows that appear to increase cow comfort. Similarly to SY, in CBP, cows are provided with an open bedded pack area for resting and exercise rather than the individual stalls and concrete alleys in FS systems. However, in CBP, unlike conventional SY, the entire pack is cultivated 1 to 3 times per day, and the area per cow required is generally higher than that in other housing systems. Although cow excreta are mixed into the bedding, thus potentially increasing the risk of poor cow hygiene, properly managed CBP can provide a health-promoting, dry, and comfortable surface on which cows can lie, stand, and walk. Because the animals can walk freely within the barn, the term "freewalk housing" has been used to describe this system (Galama et al., 2011; Bewley et al., 2017).

\section{Different Types of Cultivated Pack Barns}

According to Wagner (2002), CBP were first developed in Virginia during the 1980s with the aims of in- creasing cow comfort, improving longevity, and reducing initial barn costs. However, the CBP housing system has garnered strong global interest in the past decade. Experience with CBP from the United States (Janni et al., 2007; Barberg et al., 2007a; Black et al., 2013), Canada (LeBlanc and Anderson, 2013), Israel (Klaas et al., 2010), Denmark (Svennesen et al., 2014), the Netherlands (Galama, 2014), Austria (Ofner-Schröck et al., 2015; Burgstaller et al., 2016), Switzerland (Ghielmetti et al., 2017), Spain (Astiz et al., 2014), Italy (Leso et al., 2013), Brazil (Fávero et al., 2015a), Japan (Saishu et al., 2015), and South Korea (Galama et al., 2011) has been reported in the literature. Although all CBP worldwide share some similar characteristics, notable differences can be found among the systems developed in different countries and climates. In fact, an open bedded area and frequent pack cultivation appear to be the only features that the different CBP systems have in common.

In the United States, the management and design of CBP focus on heat production in the pack (Janni et al., 2007). In this type of CBP, the area per cow is smaller than that in other CBP systems, and the most important issue is maintaining adequate chemical and physical characteristics of the substrate to promote microbial activity, which produces heat and in turn supports pack drying (Black et al., 2013; Eckelkamp et al., 2016a). The first CBP in Israel was developed in 2006; since then, the system spread rapidly in the country. Israeli CBP are based on the concept of providing cows with large spaces. Owing to the warm and dry climate and large area per cow, little to no bedding is needed to keep the pack dry (Klaas et al., 2010). Although CBP in Israel are also regularly cultivated, less emphasis appears to be placed on heat development in the pack compared with CBP in the United States. Currently, CBP are the major housing system in Israel, even though published information about the development of CBP in Israel remains sparse. American and Israeli CBP concepts are quite different and appear to have provided a basis for development of other systems worldwide.

The CBP housing system has spread in Europe in the past decade. In 2009-2010, the first CBP were built in the Netherlands. Initially, Dutch producers developed 2 CBP systems, one based on the concept of US CBP (focusing on the production of heat in the pack) and the other more similar to Israeli CBP (based on large space allowances). The CBP system was introduced in Austria in 2011 and gained popularity due to its potential animal welfare benefits. The Austrian system appears to be similar to the US CBP, but producers have developed different designs and management styles to adapt to the microclimates in the country (A. Zentner, 
LFZ Raumberg-Gumpenstein, Irdning-Donnersbachtal, Austria, personal communication). In Italy, CBP appeared in 2006 as retrofits of SY barns (Leso et al., 2013), whereas the first specially designed CBP were not built until 2013-2014. More recently, in Europe some farms with CBP systems have been reported in Germany, Sweden, Slovenia, Bulgaria, Slovak Republic, Finland, and Norway, but information about these systems remains lacking in the literature (A. Kuipers, Wageningen University and Research, the Netherlands, personal communication).

In Brazil, CBP have become increasingly common because they provide a low-cost alternative for confinement of dairy cows. The first compost barn facility was built in 2012 in São Paulo State, with the goal of increasing animal welfare (F. A. Damasceno, Federal University of Lavras, Brazil, personal communication). Initially, Brazilian CBP were designed according to the North American model. Currently, the exact number of CBP facilities in Brazil is unknown, but the number of new CBP facilities is growing rapidly, mainly in south and southeast Brazil. The use of CBP housing is also spreading in Argentina (F. A. Damasceno, Federal University of Lavras, Brazil, personal communication). Other sources have reported that CBP have also been built in Asia and Oceania (Galama et al., 2011; Woodford et al., 2018), but little information about them is available in the scientific literature.

\section{CPB Design}

In CBP, cows are provided with an open bedded area where they can walk and rest. Because no individual stalls are included in CBP, the resting and exercise areas are combined. Manure produced in the bedded area, usually mixed with organic material, is solid and can be used for direct land application, stored for delayed use, or further composted. In most cases, CBP have a separate concrete feed alley, which allows the manure produced by the cows during feeding to be kept separate from the bedded pack. Slurry produced in the feed alley must be stored in dedicated facilities for liquid manure (Bewley et al., 2017).

The feed alley should be sufficiently large to allow the passage of 2 cows in opposite directions while another cow is eating at the feed fence. Janni et al. (2007) recommended a width of $3.6 \mathrm{~m}$ for the scraped feed alley in CBP. More recent studies have suggested that a larger width $(4-5 \mathrm{~m})$ is desirable in CBP to prevent spoilage of the pack area adjacent to the feed alley (Leso, 2015). In addition, to keep moisture away from the bedding, water troughs should be installed in the feed alley (Janni et al., 2007).
Typically, CBP in the United States have a 1.2-mhigh retaining wall surrounding the pack. The wall that separates the pack and feed alley has walkways to provide cow and equipment access to the pack area (Janni et al., 2007). In contrast, in most European CBP, the floor beneath the pack is built at a lower level than the feeding area so that the entire surface inside the barn is flat (Galama et al., 2011). In this type of CBP, the pack can be separated from the feed alley with gates. Particular attention should be paid to the design of passageways to ensure uniform utilization of the bedded area (Leso, 2015).

The depth of the bedded pack can vary widely from $20 \mathrm{~cm}$ to more than $1 \mathrm{~m}$ depending on pack management and the amount of bedding used. The level of the floor under the bedded area should be designed to maintain the surface of the pack at the same level as the floor of the feed alley. Floors placed too low can result in a deep step between the alley and the bedded area, thus limiting the cows' ease of movement. In contrast, floors that are too high may lead to excessive bedding leakage on the feed alley. Experience with CBP in the Netherlands has suggested that a minimum pack depth of $50 \mathrm{~cm}$ is needed to maintain enough heat in the pack to support the composting process (Galama et al., 2014). Therefore, the floor under the pack should be placed at least $50 \mathrm{~cm}$ below the level of the feed alley.

With the aim of enhancing the composting process, automatic systems that blow or suck air into the pack have been used in CBP in the Netherlands. Such aeration systems mainly consist of perforated tubes that are installed in the concrete floor below the pack and are connected to an external air pump (Galama et al., 2011).

The bedded area per cow is one of the most important parameters in CBP design. Janni et al. (2007) recommended a minimum pack area of $7.4 \mathrm{~m}^{2} /$ cow for a 540-kg Holstein cow or $6.0 \mathrm{~m}^{2} /$ cow for a 410-kg Jersey cow. Barberg et al. (2007a) reported an average pack area of $8.6 \mathrm{~m}^{2} /$ cow in $12 \mathrm{CBP}$ in Minnesota. In a survey including 44 CBP in Kentucky, Black et al. (2013) found that producers allocated $9.0 \mathrm{~m}^{2}$ of bedded pack/cow. Recent studies from the United States have suggested a minimum of $9.3 \mathrm{~m}^{2} /$ cow for CBP because higher densities may increase pack compaction and cause excessive moisture. A larger area per Holstein cow is required for higher milk production to increase bed drying because these cows produce relatively higher water quantities in the feces and urine. In Israel, allocating at least 15 $\mathrm{m}^{2}$ of bedded area/cow is recommended (Klaas et al., 2010). Experience in CBP in the Netherlands suggests that, to keep the pack sufficiently dry and limit the amount of bedding needed, a bedded area of $15 \mathrm{~m}^{2} / \mathrm{cow}$ 
is desirable, although with pack aeration systems and consistent composting, $12 \mathrm{~m}^{2} /$ cow may be adequate (Galama, 2014).

Austrian researchers have suggested a minimum bedded area of $7 \mathrm{~m}^{2} /$ cow for CBP, but as much as $15 \mathrm{~m}^{2} /$ cow can be allocated to facilitate bedding management (A. Zentner, LFZ Raumberg-Gumpenstein, Austria, personal communication). In Italian CBP, an average bedded area of $6.8 \mathrm{~m}^{2} /$ cow has been reported (Leso et al., 2013), although the authors stated that this area was not sufficient to maintain adequate pack conditions and led to a high requirement for bedding materials. The need for bedding material has been reported to decrease by $0.83 \mathrm{~m}^{3} /$ cow per year with each $1-\mathrm{m}^{2}$ increase in area per cow (Leso et al., 2013). Leso (2015) estimated that $14.6 \mathrm{~m}^{2} / \mathrm{cow}$ is the optimal bedded area for CBP located in northern Italy. In a Brazilian study involving $3 \mathrm{CBP}$, the bedded area per cow ranged from 11 to $19 \mathrm{~m}^{2}$ /cow (Fávero et al., 2015b). Owing to different climatic conditions, the recommended area per cow for CBP in Brazil is 10 and $12 \mathrm{~m}^{2} /$ cow for the midwest and southeast regions of the country, respectively (F. A. Damasceno, Federal University of Lavras, Brazil, personal communication).

The area per cow in different CBP systems can vary widely depending on several factors. Because evaporation mainly occurs at the surface of the pack, increasing the area per cow in CBP generally results in drier bedding and reduced utilization of bedding materials, thereby decreasing running costs. However, a larger area per cow is also associated with higher initial barn costs. For this reason, the cost and availability of bedding as well as barn construction costs should be considered when designing CBP. A larger area per cow is recommended when the availability and cost of bedding materials are limiting or the construction cost is low, whereas decreasing the barn surface may be convenient in situations in which the bedding materials are inexpensive and readily available or construction costs are high (Leso, 2015).

Furthermore, heat developed by the composting process occurring within the pack can increase the drying rate. Consequently, CBP design varies with pack management style and the type of bedding used. In CBP systems based on the use of wood materials, such as in the US CBP, the pack can reach relatively high temperatures, which facilitates evaporation and in turn reduces the area needed to keep the bedding adequately dry. Smits and Aarnink (2009) studied evaporation in CBP by using a model approach. They estimated the drying rate from a cultivated bedded pack by including environmental parameters (e.g., air temperature, relative humidity, and air velocity) and variables regarding the composting process in the model. The results re- vealed that environmental conditions are major factors influencing the drying rate and that heat produced by the composting process can considerably improve evaporation from the pack. Under Dutch climatic conditions (with air velocity above the pack ranging from 0.08 to $0.32 \mathrm{~m} / \mathrm{s}$ ), the drying rate of a pack that is actively composting may reach $3.6 \mathrm{~kg} / \mathrm{m}^{2}$ per day (which is equivalent to $3.6 \mathrm{~mm}$ of pan evaporation in meteorological terms), whereas a noncomposting pack scarcely exceeds $1 \mathrm{~kg} / \mathrm{m}^{2}$ per day (equivalent to $1 \mathrm{~mm}$; Smits and Aarnink, 2009).

Climate can also affect CBP design because the pack drying rate is strictly associated with air conditions (Eckelkamp et al., 2016a). Generally, the required space allowance decreases with increasing drying rate. In warm, dry, and windy weather, rapid pack drying is likely to occur, thus potentially decreasing the pack area needed to keep the pack adequately dry. In cold and humid conditions, the pack drying rate is instead limited, and a larger area per cow may be needed to reduce pack moisture (Smits and Aarnink, 2009). Black et al. (2013) investigated pack drying rates in CBP by using a mass transfer equation. Evaporation was found to be associated with ambient temperature, relative humidity, air velocity, and pack surface temperature. As expected, the drying rate significantly reduced pack moisture. The authors suggested that although producers have limited control over air temperature and relative humidity, air velocity can be enhanced by proper barn ventilation and fan circulation, which can improve pack drying.

To maximize natural ventilation, sidewall heights of 4 to $5 \mathrm{~m}$ are recommended for CBP barns. A roof pitch of at least $4: 12$ and a ridge vent opening of at least $2.5 \mathrm{~cm}$ for every $1.0 \mathrm{~m}$ of roof width with a minimum opening width of $30.5 \mathrm{~cm}$ have also been suggested (Bewley et al., 2012). Furthermore, wide roof overhangs (at least $1 \mathrm{~m}$ ) are necessary to prevent rainwater from entering the pack. In temperate climates, the ventilation needs of CBP may vary between the summer and winter periods. During summer, maximizing sidewall open area is essential to remove heat and moisture created by the cows as well as the additional heat and moisture created by the composting process. In winter, excessive air speed may instead lead to excessive heat loss from the pack, which limits the pack drying rate and results in wetter bedding (Smits and Aarnink, 2009). Sidewall curtains can help minimize the negative effects of winds and inclement weather during winter while maximizing natural ventilation in summer (Bewley et al., 2012).

Mechanical ventilation can also be used in CBP to promote pack drying as well as to control cows' heat stress during hot periods. High-volume, low-speed ceiling fans are a commonly used solution in CBP, but 
conventional panel or basket fans may also be used. Pad cooling and misting systems may not be appropriate for CBP, especially over the bedded area, because an increase in relative humidity would decrease the evaporation rates. Sprinkling systems can be installed over the feeding area in $\mathrm{CBP}$ with a separate concrete feed alley. When designing ventilation in CBP, particular attention should be paid to obtaining uniform airflow within the barn. During heat stress conditions, cows may congregate in areas where airflow is higher, thus leading to manure and urine accumulation over the pack.

Another important factor to consider when designing CBP is building orientation, which affects the ventilation and sunlight exposure of the barn. The ideal orientation depends on several factors. To maximize natural ventilation, barns should be oriented so that the prevailing summer winds are perpendicular to the barn ridge (Gooch, 2008). Because wind direction is highly site specific, an east-west orientation is generally preferred because it minimizes barn interior exposure to sunlight. Penetration of direct sunlight increases the cow thermal load and therefore must be avoided, especially during summer. Nevertheless, in the case of CBP, the sunlight exposure of the pack surface may improve evaporation and reduce bedding utilization, especially during winter months (Galama, 2014).

\section{Alternative Building Solutions for CBP}

To maximize sunlight exposure of the bedded pack, several CBP in the Netherlands have been built using greenhouse-type structures with transparent or semitransparent claddings (Galama et al., 2011). Experience with this type of building suggests that a transparent roof can decrease the amount of bedding needed to maintain adequate hygienic conditions of the pack. Greenhouse structures also enable better control over barn ventilation because most of them have automatic systems to control both sidewalls and ridge opening. Another advantage of the greenhouse structure is the lower construction cost compared with conventional buildings (Galama et al., 2011).

Greenhouse-type structures may not be suitable for warm climates because transparent coverings are likely to result in high heat stress for cows during summer months. However, experience in the Netherlands indicates that specific shading systems can help control temperatures in greenhouse-type structures (Galama et al., 2011). Leso et al. (2017) evaluated greenery systems as an alternative solution to reduce thermal load in greenhouse-type buildings. The results indicated that under hot weather conditions, a greenhouse-type structure with a plant canopy had the same internal temper- ature as a building with an insulated roof. Plants have also been planted within a greenhouse-type dairy barn, known as the cow garden, in the Netherlands (Galama et al., 2011; Bewley et al., 2017). In this particular case, plants were used primarily with the aim of creating a more natural environment for the cows but also to provide shading. However, this concept can create barriers to, or channeling of, air movement within the barn, thus resulting in uneven airflow patterns.

Other alternative covering solutions for $\mathrm{CBP}$ have been reported from Israel, where some producers have installed a retractable roof that improves control over barn ventilation and sunlight exposure (Galama et al., 2011). Finally, unlike conventional housing systems such as FS, CBP can potentially decrease the use of cast-in-place concrete and allow the emerging principle of "design for deconstruction" to be extensively applied. Design for deconstruction is becoming an important part of green building design; it embraces methods that facilitate the reuse of building components at the end of a structure's life (Kanters, 2018). An experimental CBP designed for complete end-of-life disassembly and reuse of building materials was recently built and tested in Italy and yielded encouraging results (Leso et al., 2018).

\section{Pack Management and Temperature}

In all CBP systems, pack management should aim at providing a hygienic and comfortable surface for the cows. The most important characteristic of the pack is its moisture content. Wet bedding may adhere to cows, thus resulting in dirty animals and consequently increasing the risk of mastitis and longer teat preparation times in milking (Black et al., 2013). The moisture level of the pack has been shown to affect cow cleanliness, udder health, and ease of movement (Eckelkamp et al., 2016a). The optimal moisture level for a cultivated pack ranges between $40 \%$ and 60 to $65 \%$ (Janni et al., 2007; Black et al., 2013). To keep the moisture level in the optimal range, water produced by the animals through excreta must be absorbed or evaporated. Absorbing water in excess requires the addition of dry bedding materials and thus is likely to increase running costs. To limit the amount of bedding needed, evaporation of water from the pack must be encouraged. By maintaining an active composting process, the temperature of the pack can be increased, thus promoting evaporation. Table 1 provides an overview of the main results found in the literature regarding pack management in CBP.

Frequent and consistent pack cultivation is essential for CBP management. When walking and lying down, the animals compact the bed surface, thus reducing the porosity of the material and consequently decreasing 
the amount of oxygen available for the composting process and the pack surface exposed for drying. Cultivation restores pack porosity, thereby enhancing the composting process and pack drying (Janni et al., 2007; Damasceno, 2012), and allows for incorporation of fresh manure into the top layer of the organic pack, thus providing a cleaner lying surface for the cows (Shane et al., 2010).

In most CBP, pack tilling is performed with a modified cultivator on a skid loader or small tractor. Some farmers use a rototiller, and some use a combination of rototiller and tine cultivator (Barberg et al., 2007a). In most US CBP, the pack is cultivated 2 times per day, even though some producers chose to till 1 or 3 times per day, depending on management (Barberg et al., 2007a; Black et al., 2013, 2014). In the Israeli CBP, the pack is cultivated mostly once per day (Klaas et al., 2010). Similarly, most producers in the Netherlands and Denmark cultivate the pack once per day (Galama, 2014; Bjerg and Klaas, 2014). However, in most Dutch

Table 1. Management-related parameters in compost-bedded pack barns

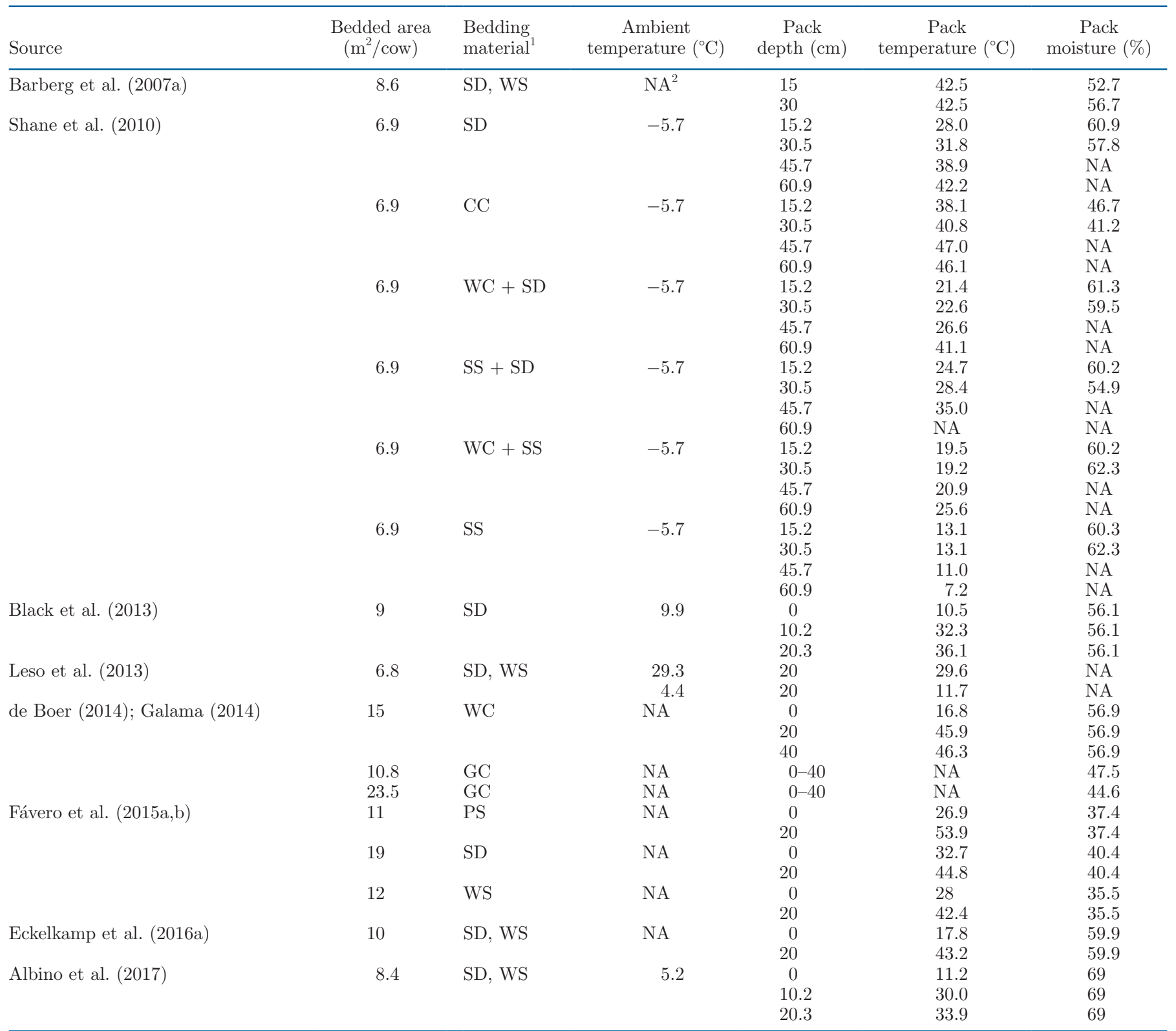

${ }^{1} \mathrm{SD}=$ sawdust; $\mathrm{WS}=$ wood shavings; $\mathrm{CC}=$ corncobs; $\mathrm{WC}=$ wood chips; $\mathrm{SS}=$ soybean straw; $\mathrm{GC}=$ green waste compost; PS = peanut shells. ${ }^{2}$ Not available. 
CBP, the pack is aerated many times per day (usually every $2 \mathrm{~h}$ ) by an aeration system installed in the floor below the pack (Galama, 2014). In Italian CBP, pack cultivation occurs 1.4 times per day and requires 41 $\mathrm{min} / \mathrm{d}$ on average (Leso et al., 2013).

The pack should be cultivated at a depth of 25 to $30 \mathrm{~cm}$ (Janni et al., 2007). Increasing the cultivation frequency and depth leads to higher pack temperature. Black et al. (2013) found an approximately $10^{\circ} \mathrm{C}$ difference between pack cultivated once versus twice daily, and cultivation depth is positively associated with pack temperature. However, during winter, frequent aeration may result in an excessive heat loss from the pack, thus disturbing the composting process. For this reason, some Dutch producers have modified pack management during colder months, reducing both cultivating frequency and depth (Galama, 2014). Ideally, in CBP, the pack temperature at a depth of 15 to $31 \mathrm{~cm}$ ranges from 43.3 to $65.0^{\circ} \mathrm{C}$ (Janni et al., 2007; Bewley et al., 2013).

Barberg et al. (2007a) studied CBP in Minnesota and reported a mean pack temperature of $42.5^{\circ} \mathrm{C}$ at depth of $20 \mathrm{~cm}$. In Kentucky CBP, the mean pack temperature at the surface has been found to be $10.5^{\circ} \mathrm{C}$, a value very similar to ambient temperature $\left(9.9^{\circ} \mathrm{C}\right)$, probably because evaporation and ventilation cooled the surface of the pack (Black et al., 2013). The pack temperature tended to increase with depth, and the maximum temperature was found at the bottom of the tillage layer. The temperatures measured at pack depths of 20.3 and $10.2 \mathrm{~cm}$ were 36.1 and $32.3^{\circ} \mathrm{C}$, respectively. The pack temperature at $20.3 \mathrm{~cm}$ depth was affected by the ambient temperature, tilling frequency, and tilling depth. Later studies on CBP also found that the pack internal temperature increased and pack moisture decreased with increasing air temperature (Eckelkamp et al., 2016a).

In 10 CBP in northern Italy, Leso et al. (2013) reported that the pack temperature at a depth of $20 \mathrm{~cm}$ was higher in the summer $\left(29.6^{\circ} \mathrm{C}\right)$ than in the winter $\left(11.7^{\circ} \mathrm{C}\right)$. In both summer and winter, the pack temperatures were not high enough for a proper composting process to be identified. However, the difference between the pack and air temperatures measured on some farms in winter appears to suggest that the pack is biologically active. On the basis of experience from CBP in the Netherlands, in CBP using wood chips and aeration systems, the pack temperature at a depth of $20 \mathrm{~cm}$ ranged from 34.6 to $57.7^{\circ} \mathrm{C}$, whereas in CBP with no aeration systems using organic waste compost as bedding, the pack temperature at the same depth was between 16 and $34^{\circ} \mathrm{C}$ (Galama, 2014).

Because heat production within the pack is thought to improve the drying rate, maintaining optimal pack chemical and physical characteristics in CBP is important to support rapid and consistent bacterial growth. The composting process in CBP may be affected by several parameters, most importantly pack moisture, $\mathrm{pH}$, oxygen availability, and carbon to nitrogen $(\mathbf{C : N})$ ratio. Stentiford (1996) indicated that higher compost temperatures tend to be achieved when the pack moisture is between 40 and $60 \%$. Studies on the composting process have indicated that faster $\mathrm{OM}$ degradation occurs when the $\mathrm{C}: \mathrm{N}$ ratio is in the range of $25: 1$ to $30: 1$ and the $\mathrm{pH}$ remains below 8 (FAO, 2003). Because aerobic processes produce more energy than anaerobic processes, high oxygen availability is crucial for optimal composting (FAO, 2003).

In addition, dairy cow feces have a low C:N ratio, ranging from 15:1 to 19:1 (Rynk et al., 1992; Leonard, 2001). Most commonly used bedding materials are dry and have a very high C:N ratio. Rynk et al. (1992) reported C:N ratios of 600:1, 442:1, and 127:1 for wood chips, sawdust, and wheat straw, respectively. In CBP, adding fresh bedding may be necessary to absorb excessive pack moisture and to keep the pack C:N ratio within the optimal range. Galama (2014) suggested that the barn should be cleaned out and a new pack should be started when the pack decreases to a C:N ratio of 15:1. Below this level, composting appears to be inhibited in CBP, and higher losses of nitrogen may occur.

Normally, the pack area in CBP provides bedding storage for 6 mo to 1 year (Barberg et al., 2007a; Galama, 2014). Therefore, the barn must be cleaned every 6 to 12 mo before a new pack is started. In temperate climates, a complete cleanout during late fall is recommended to allow reestablishment of the composting process with fresh material before the start of winter weather (Galama et al., 2014; Janni et al., 2007). To start a new cultivated pack, most producers in the United States lay down 25 to $50 \mathrm{~cm}$ of fresh bedding (Janni et al., 2007). Nevertheless, the initial pack depth can vary widely among farms, ranging from 3.5 to 121.9 $\mathrm{cm}$. In addition, some producers choose to retain some of the old material in the barn after cleanout (Black et al., 2013). Producers with CBP in Italy have started a new pack, adding 10 to $20 \mathrm{~cm}$ of organic bedding (Leso et al., 2013). Experience from CBP in the Netherlands suggests that maintaining heat in the pack requires a pack depth of at least $50 \mathrm{~cm}$ (Galama, 2014). Therefore, starting a new pack with at least 50-cm depth may allow an adequate composting process to be achieved in an early stage.

Compost-bedded pack barns require periodic addition of fresh bedding. In most Minnesota CBP, the amount of bedding added at one time provides 10 to $20 \mathrm{~cm}$ of fresh bedding across the pack (Barberg et 
al., 2007a). Another survey showed that in Kentucky CBP, new bedding is added every $16.4 \mathrm{~d}$ during winter and every $18.2 \mathrm{~d}$ in summer. On average, Kentucky producers add a mean depth of $8.8 \mathrm{~cm}$ of shavings per bedding addition, ranging from 0.1 to $35.3 \mathrm{~cm}$ (Black et al., 2013). In Dutch CBP with aeration systems, wood chips should be added at least every month during the winter period (Galama, 2014). Producers in Italy add fresh bedding every $12 \mathrm{~d}$ on average, and bedding additions are more frequent in winter than in summer (Leso et al., 2013). In Austrian CBP, fresh bedding is added every 2 to $7 \mathrm{wk}$. Owing to the dry weather and large area per cow, no bedding is used in CBP in Israel (Klaas et al., 2010).

Adding fresh bedding at the correct time is crucial in CBP because a delay in bedding addition may result in rapid deterioration of pack conditions. The first reports regarding $\mathrm{CBP}$ management recommend adding bedding when the material tends to stick to the cows (Barberg et al., 2007a; Janni et al., 2007). However, Black et al. (2013) found that cow hygiene and udder health are likely to be compromised at that point. Instead, adding shavings depending on the pack moisture content appears to be a more viable recommendation. The combination of manure and substrate should not exceed a moisture content of $70 \%$, whereas a range of 50 to $60 \%$ is preferred (Black et al., 2013).

Precise on-farm monitoring of pack moisture in CBP may pose some challenges because material sampling and testing procedures (based on dry and weigh methods) are laborious. However, practical experience in CBP suggests that pack moisture can be estimated with reasonable accuracy using a simple squeeze test (Bewley et al., 2013). As research on CBP progresses, new management tools will probably become available. Mota et al. (2018) developed a fuzzy classifier to aid in decision making regarding the control of variables such as bed moisture, pack temperature, and bedding aeration in CBP. Evans et al. (2017) studied an automated calibration method of electrochemical oxygen sensors for use in CBP and found encouraging results. Oxygen was found throughout the tillage depth immediately after tillage. Depletion of oxygen occurred at all tillage depths during the time period after tillage, and the oxygen at the bottom of the tillage layer was near $0 \%$ after $1 \mathrm{~h}$. Measuring the oxygen concentration indeed has potential in improving CBP management.

\section{Bedding Materials}

In early studies on CBP in Minnesota, sawdust and wood shavings were recommended, and ground soybean straw was listed as a viable alternative (Barberg et al., 2007a; Janni et al., 2007). Producers with CBP in
Kentucky have used green or kiln-dried shavings and sawdust, and a mixture of soy hulls with shavings and sawdust (Black et al., 2013). In the Netherlands, CBP with aeration systems require the use of wood chips because the relatively large particle size prevents excessive compaction and allows air to pass through the pack (Galama et al., 2011). In Italy, producers have used sawdust and a mixture of sawdust and wood shavings (Leso et al., 2013). In addition, in CBP in Brazil, the use of sawdust and wood shavings is common (Mota et al., 2017), but other materials such as rice straw and coffee husks have also been widely used.

Wood materials appear to be particularly suited to CBP, owing to their high energy content and high C:N ratio. Sawdust is appreciated for its high absorption capacity, whereas adding shavings or wood chips may be beneficial to maintain a loose structure in the pack. However, the use of fresh or wet sawdust reduces the water absorption capacity and may pose a risk of mastitis due to increased concentrations of Klebsiella spp. (Janni et al., 2007; Bewley et al., 2013). In addition, the availability of wood materials is limited in most regions, and their cost is increasing because of the high demand in the wood-energy market. High costs and limited availability of bedding materials are producers' main limitations regarding CBP housing systems (Barberg et al., 2007b; Leso et al., 2013).

Flexibility in bedding choice may play an important role in determining the economic sustainability of CBP systems. Shane et al. (2010) tested several different substrates, including pine sawdust, corn cobs, pine wood chip fines, and soybean straw, and found that almost any organic material can work in CBP if proper bedding management is applied on a consistent basis. The authors concluded that ideal bedding material for CBP should be dry, be processed to less than $2.5 \mathrm{~cm}$ long, offer structural integrity, and have good water absorption and water-holding capacity.

Alternative materials used in CBP include cereal straw, corn stalks, coconut fiber, coarse hay, coffee husks, peanut shells, dried manure, and compost from organic waste (Bewley et al., 2017). Straw and corn stalks are not recommended for use in CBP due to difficulties in cultivating with normal equipment and excessive pack compaction (Janni et al., 2007). In addition, deep straw bedding in SY is known to increase the risk of mastitis (Peeler et al., 2000) and the prevalence of dirty cows (Fregonesi and Leaver, 2001). Nevertheless, in recent years, some Dutch producers have begun to use straw in CBP as an alternative to compost and have found encouraging results. Galama et al. (2014) reported that cows housed in CBP bedded with straw have very low SCC. Regardless of the type of bedding, frequent pack cultivation and a larger area per cow 
appear to promote better udder health in CBP than in conventional deep bedding systems such as SY (Barberg et al., 2007b). Fine processing of corn cobs and any type of straw is strongly suggested for use in CBP. Such fine materials may be used in a mixture with sawdust or other wood materials. Some experience in $\mathrm{CBP}$ with inorganic bedding materials (e.g., sand and waste wallboard) has been reported in the literature. Inorganic materials have been shown to be unsuitable for use in CBP because they do not promote composting (Galama et al., 2011). Gypsum from wallboard produces hydrogen sulfide under anaerobic conditions and consequently can have health effects on operators during removal of the anaerobic layer during cleanout (Fabian-Wheeler et al., 2017). An active microbial aerobic compost layer can act as a biofilter throughout the year to oxidize the hydrogen sulfide gases diffusing from the anaerobic layer.

Compared with FS, CBP generally require a greater amount of bedding material (Black et al., 2013). Janni et al. (2007) estimated that CBP in Minnesota require $19.6 \mathrm{~m}^{3} /$ cow per year of dry fine sawdust, on average. Black et al. (2013) found that bedding utilization in Kentucky CBP ranges from 18.6 to $25.6 \mathrm{~m}^{3}$ /cow per year for producers using fresh and kiln-dried sawdust or shavings. Galama (2014) reported that a CBP with a pack ventilation system in the Netherlands requires approximately $5 \mathrm{t}$ of wood chips/cow per year, whereas a CBP with household compost requires $8.3 \mathrm{t} /$ cow per year. Leso et al. (2013) found an average bedding utilization of $8.2 \mathrm{~m}^{3} /$ cow per year in Italian CBP using mainly sawdust and wood shavings.

\section{ANIMAL WELFARE IN CBP}

The CBP housing system was developed primarily to improve cow comfort and longevity (Janni et al., 2007). Compost-bedded pack barns are thought to be healthier for cows than FS housing systems due to the lower exposure to concrete surfaces and injury-causing obstacles (Bewley et al., 2017). In addition, CBP are sometimes perceived to provide more natural living conditions for housed animals (Endres and Barberg, 2007). Several published studies have focused on cow welfare and behavior in CBP; the main results are summarized in Table 2.

\section{Lameness and Hock Lesions}

The prevalence of lameness is reported as the proportion of cows with a locomotion score $\geq 3$ on a 1 -to- 5 scale $(1=$ normal and $5=$ severely lame; Flower and
Weary, 2006), and the prevalence of severe lameness refers to the proportion of cows with a locomotion score $\geq 4$ on the same scale. The prevalence of hock lesions is defined as the proportion of cows with a lesion score $\geq 2$ on a 1 -to- 3 scale $(1=$ normal, $2=$ mild lesions, and 3 = severe lesions; Nocek, 2010), and severe hock lesion is defined as the percentage of cows with a lesion score of 3 on the same scale.

Fulwider et al. (2007) compared hock lesions in cows housed in $\mathrm{CBP}$ and in FS with different types of bedding. Cows in CBP had no lesions, whereas in FS with rubber-filled mattresses, sand, and waterbeds, the hock lesion prevalence was $71.4,25.0$, and $35.2 \%$, respectively. Lobeck et al. (2011) found that prevalence of lameness, hock lesions, and severe hock lesions was lower in $\operatorname{CBP}(4.4,3.8$, and $0.8 \%$, respectively) than in cross-ventilated FS $(15.9,31.2$, and $6.5 \%$, respectively) and naturally ventilated FS (13.1, 23.9, and 6.3\%, respectively). The housing systems did not differ in severe lameness prevalence. Eckelkamp et al. (2016b) compared the locomotion of cows housed in CBP and FS (sand bedded) and found no significant differences in the prevalence of lame and severely lame cows. Hock lesions also did not differ between housing systems.

Borchers (2018) tested for the presence of digital dermatitis-associated spirochete bacteria, Treponema sp., in beds of CBP $(\mathrm{n}=3)$ and FS bedded with sand $(\mathrm{n}=$ 4). Treponema sp. were found in all barns in both winter and summer. Treponema pedis, Treponema phagedenis, and Treponema medium were not found in any bedding samples in either housing type. These species are the most common causative agents of digital dermatitis in dairy cattle (Biemans et al., 2018).

Ofner-Schröck et al. (2015) found a lameness prevalence of $25.4 \%$ in CBP and noted that this percentage is significantly lower than results obtained in a previous study including FS barns (45.7\%). More recently, Burgstaller et al. (2016) found no significant differences in lameness prevalence between cows housed in CBP and FS (18.7\% vs. 14.9\%). However, significant differences in the prevalence of specific claw disorders were found between CBP and FS, including white line disease (20.4\% vs. $46.6 \%$ ), heel horn erosion (26.9\% vs. $59.9 \%$ ), concave dorsal wall as a result of chronic laminitis (6.5\% vs. $15.9 \%)$, and interdigital hyperplasia $(0.2 \%$ vs. $3.1 \%)$.

Klaas et al. (2010) found no evidence of hock or other body lesions in CBP. In a recent study, Costa et al. (2018) compared lameness and lesions in cows housed in $\mathrm{CBP}$, FS, and FS dairies that used CBP only for vulnerable cows (transition and sick cow pens; FS + CBP). The prevalence of both lame and severely lame cows was lower in CBP (31.9 and 14.2\%) than in FS 
Leso et al.: INVITED REVIEW: COMPOST BARNS FOR DAIRY COWS

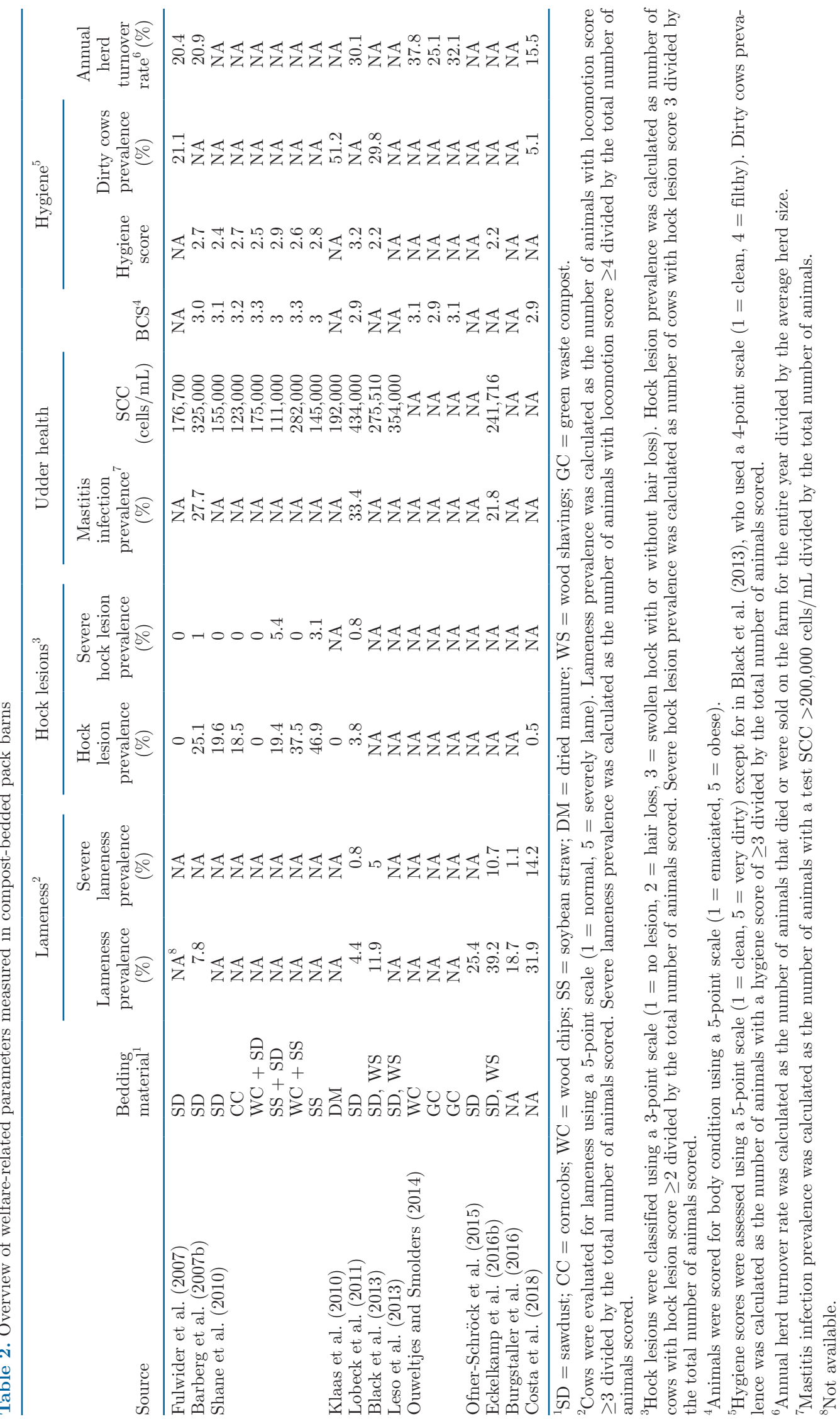


(43.2 and $22.2 \%$ ) and FS + CBP (45.4 and $22.2 \%$ ). In the same study, a significantly lower prevalence of hock lesions was found in cows housed in CBP $(0.5 \%)$ than in FS $(9.9 \%)$ and FS + CBP $(5.7 \%)$.

Overall, the results reported in the literature suggest that $\mathrm{CBP}$, compared with FS, has the potential to improve foot and leg health. Producers with CBP have also indicated that they were able to keep lame cows in the herd longer because the cows could more easily stand up and lie down on the bedded pack area (Barberg et al., 2007b). However, the reported results are not completely consistent, and large variations have been reported in the prevalence of both lameness and hock lesions (Table 2). An important source of variation appears to be associated with the type of material used as bedding. Shane et al. (2010) compared several bedding materials (sawdust, corn cobs, a mixture of wood chips and sawdust, a mixture of soybean straw and sawdust, a mixture of wood chips and soybean straw, and soybean straw) in CBP and found considerable differences in hock lesion prevalence associated with different types of bedding. The mixture of wood chips and sawdust had the lowest hock lesion prevalence $(0 \%)$, whereas soybean straw had the highest hock lesion prevalence (46.9\%). Moreover, among all materials tested, only cows housed in CBP bedded with soybean straw and the mixture of soybean straw and sawdust had severe hock lesions (Shane et al., 2010). This finding suggests that the choice of bedding materials in CBP can affect the prevalence of hock lesions and potentially lameness.

\section{Cow Hygiene}

If not otherwise stated, cow hygiene is reported as the hygiene score measured on a 1-to- 5 scale $(1=$ clean and 5 = very dirty; Reneau et al., 2005), and the prevalence of dirty cows is expressed as the proportion of animals with hygiene score $\geq 3$ on the same scale. Lobeck et al. (2011) evaluated the hygiene of cows in 3 different housing systems. The mean hygiene scores were $3.18,2.83$, and 2.77 for CBP, cross-ventilated FS, and naturally ventilated FS, respectively, and the scores for CBP were significantly higher than those for the other systems. A significant interaction between housing system and season was also observed. The CBP barns had higher hygiene scores than both FS systems during winter, whereas no significant differences were detected in the other seasons.

In another farm survey including CBP, Black et al. (2013) found that ambient temperature, pack temperature, and the interaction between moisture and ambient temperature significantly affect the mean herd hygiene in CBP. Cold and humid ambient conditions (which decrease pack drying rate and in turn increase pack moisture) are associated with high hygiene scores, whereas increasing pack temperature decreases the mean herd hygiene scores. In a later study, Eckelkamp et al. (2016b) reported a similar mean hygiene score in CBP (2.19 on the same 4-point scale used by Black et al., 2013) but no significant differences in hygiene from that measured in sand-bedded FS (2.26). Cow hygiene in CBP is not affected by pack temperature but increases with increasing pack moisture content and decreases as air temperature increases (Eckelkamp et al., 2016a).

Among all the studies analyzed, the highest percentage of cows scored as dirty (51.2\%) was in Israeli CBP (Klaas et al., 2010). Because of the warm climate, producers with CBP in Israel do not add any bedding materials. The authors have noted that the farms with cleaner cows had high pack temperatures, whereas a relatively high number of dirty cows were found in $\mathrm{CBP}$ in which the pack did not generate adequate heat (Klaas et al., 2010). In Austria, Ofner-Schröck et al. (2015) evaluated the cleanliness of cows housed in CBP and reported a good level of cleanliness (mean score $=0.44$ in 5 regions of the cow body on a scale of 0 to 2 , where $0=$ clean and $2=$ very dirty; Faye and Barnouin, 1985); these results were comparable with or lower than those measured in other housing systems (0.40 in FS, 0.59 in SY, and 0.77 in sloped-floor systems on the same scale). Cows in Austrian CBP have been found to be dirtier on the lower hind leg than on other body regions, including the udder. Ofner-Schröck et al. (2015) have noted that factors such as stocking density and pack management can affect the cleanliness of cows in CBP.

In a study of 3 CBP (Fávero et al., 2015a), the hygiene levels of 4 different regions of the cows (udder, leg, flank, and teats) were evaluated on a 4-point scale ( $1=$ clean and $4=$ very dirty $)$. The mean hygiene scores were $1.28,1.68,1.40$, and 1.9 for the udder, leg, flank, and teats, respectively. The cleanliness scores did not vary across seasons. However, cow hygiene was affected by bedded pack conditions, including the bedding dry and wet densities, bedding $\mathrm{OM}$, and bedding age. Costa et al. (2018) reported a higher prevalence of dirty legs $(5.0 \%)$ than udders $(0.0 \%)$ and flanks $(0.0 \%)$ in cows housed in CBP (defined as the prevalence of cows with a hygiene score $\geq 2$ on a 3 -point scale, where $1=$ clean and $3=$ soiled with large amounts of manure or dirt; Lombard et al., 2010). The prevalence of animals with dirtiness on all areas of the body was numerically higher in FS $(2.1,16.1$, and $4.0 \%$ for udder, leg, and flank, respectively) and in FS dairies that used CBP only for vulnerable cows $(2.1,14.8$, and $2.9 \%$ for 
udder, leg, and flank, respectively) than in CBP, but the differences were not statistically significant (Costa et al., 2018).

Studies regarding the hygiene of cows in CBP have shown inconsistent results, and both the hygiene scores and prevalence of dirty cows vary widely (Table 2). Compared with cows housed in FS, cows housed in CBP have comparable or poorer hygiene levels. Most authors have highlighted that the hygiene of cows in CBP depends on the conditions of the bedded pack, and pack moisture is the most important parameter. Generally, increased pack moisture results in higher hygiene scores because wet materials adhere more easily to animals (Black et al., 2013; Eckelkamp et al., 2016b). In temperate climates, cows in CBP tend to be dirtier during winter because maintaining adequately dry bedding in cold and humid weather can be challenging (Lobeck et al., 2011). In some studies, high pack temperatures have been associated with cleaner animals. The results emphasize the importance of proper pack management in CBP.

\section{Udder Health and Pack Bacteria}

In the studies included in this section, SCC is expressed as the average SCC of all cows measured by the DHI service during monthly herd checks. The prevalence of mastitis infection is defined as the proportion of cows with $\mathrm{SCC}>200,000$ cells $/ \mathrm{mL}$ on the day the data were obtained. The main results regarding mastitis in CBP are summarized in Table 2, and Table 3 provides an overview of pack bacterial analyses.

Barberg et al. (2007b) compared mastitis infection rates before and after housing of herds in CBP and found that 6 out of 9 dairies had decreased herd mastitis infection prevalence, with an average reduction of 12.0\%. Fulwider et al. (2007) found that CBP resulted in lower SCC (176,700 cells/mL) than FS with rubberfilled mattresses $(241,500$ cells $/ \mathrm{mL})$, sand $(235,200$ cells $/ \mathrm{mL})$, and waterbeds $(232,500$ cells $/ \mathrm{mL})$, although the differences were not statistically significant. Shane et al. (2010) tested different types of bedding materials in CBP and found no significant effects on SCC. Moreover, no relationship has been found between SCC and high counts of bacteria on the surface of the pack. The coliform population has been found to be numerically higher in wood materials. Other authors studying CBP have highlighted that wood materials such as wood shavings and sawdust may increase the likelihood of exposure to Klebsiella spp. pathogens (Janni et al., 2007).

Lobeck et al. (2011) found that cows housed in CBP had significantly higher SCC $(434,000$ cells $/ \mathrm{mL})$ than those housed in cross-ventilated FS (309,000 cells/mL) and naturally ventilated FS $(300,000$ cells $/ \mathrm{mL})$. The

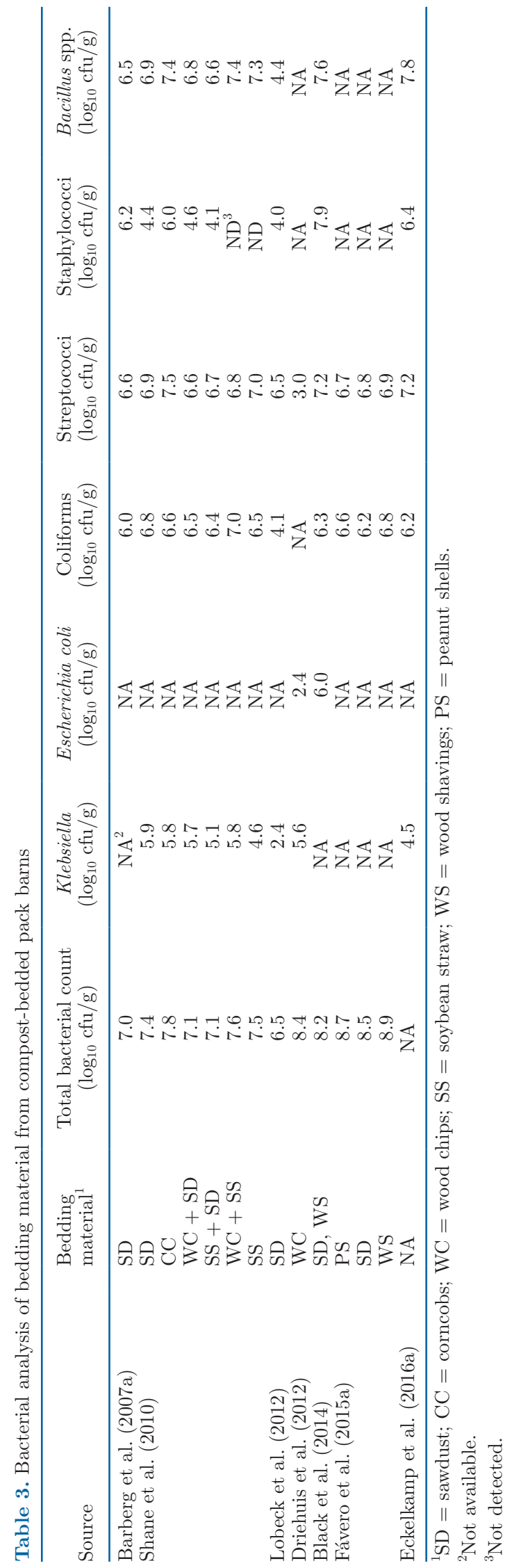


mastitis infection prevalence was $33.4,26.8$, and $26.8 \%$ in CBP, cross-ventilated FS, and naturally ventilated FS, respectively, and no significant differences were found among housing systems. The bedding bacterial counts in the housing systems were also compared (Lobeck et al., 2012), and no differences among housing systems for Klebsiella, coliforms, environmental streptococci, and Staphylococcus spp. counts were detected. However, during winter, the Bacillus spp. count was lower in CBP than in cross-ventilated and naturally ventilated FS, whereas in summer, CBP had greater Bacillus spp. levels than the other systems.

Black et al. (2014) showed that pack temperature, pack moisture, C:N ratio, and area per cow have no effect on coliform counts. Escherichia coli reached a peak concentration when the $\mathrm{C}: \mathrm{N}$ ratio was between 30:1 and 35:1. Staphylococci counts increased as the ambient temperature increased. Streptococci counts decreased with increased area per cow and pack temperature and increased with increasing ambient temperature and moisture. The streptococci counts peaked at a C:N ratio ranging from 16:1 to 18:1. The Bacillus spp. counts decreased with increasing moisture, C:N ratio, and ambient temperature.

Eckelkamp et al. (2016b) compared mastitis indicators of cows housed in CBP and sand-bedded FS. No significant differences were reported between the housing systems for SCC or for mastitis infection prevalence. In addition, the mastitis causative pathogens isolated from milk samples collected in CBP and FS did not differ. In both systems, the most frequent pathogens isolated were $E$. coli followed by environmental streptococci. Klebsiella spp. constituted a small percentage of causative pathogens in both CBP and sand-bedded FS, and the number of isolates was similar between the housing systems. In CBP, SCC and mastitis infection prevalence both have been found to increase with increasing barn air temperature but to be unaffected by compost measurements. Furthermore, an analysis of mastitis-causing pathogens in $\mathrm{CBP}$ revealed that as pack internal temperature increases, staphylococci, streptococci, and bacilli species growth in the pack decreases and coliform species growth increases. At low pack moisture and high air temperature, bacterial levels in the pack decrease (Eckelkamp et al., 2016a).

Albino et al. (2017) evaluated relationships between bacterial populations in bedding material, on teat ends, and in milk of cows housed in CBP. Although the total bacteria count (TBC) in milk remained low $(5,554 \mathrm{cfu} / \mathrm{mL})$, the mean $\mathrm{SCC}$ was 516,569 cells $/ \mathrm{mL}$, thus indicating that udders were affected by bacteria that had little influence on TBC. The total bacteria counts on teat ends were positively correlated with the cows' hygiene scores. A moderate positive correlation was also detected between TBC on teat ends and SCS. However, no significant correlations were found among specific bacterial populations (i.e., E. coli, Klebsiella spp., Streptococcus spp., and coliforms) on teat ends or in milk and SCS. On the basis of these results, the authors concluded that in CBP, indirect measures such as hygiene score may not provide reliable information regarding bacterial contamination on teat ends and in milk.

Borchers (2018) performed a study assessing the effects of housing system on milk SCC on the basis of cow hair cortisol values. The hair cortisol values were significantly higher in the cows housed in FS than in those housed in CBP. Environmental stress to lactating cows affects milk production and SCC: significantly higher milk production and lower SCC were found for CBP compared with FS.

Fávero et al. (2015a) studied factors associated with mastitis epidemiologic indexes in $3 \mathrm{CBP}$ and found that mastitis risk is affected by bedded pack conditions and cow hygiene level. The odds of a case of environmental clinical mastitis increased $5.7 \%$ for each 1-unit increase in bedding moisture, whereas the mastitis infection prevalence increased $16 \%$ for each 1-unit increase in leg cleanliness score (on a 4-point scale). Escherichia coli, CNS, and environmental streptococci were the pathogens most frequently isolated from clinical mastitis cases. Corynebacterium bovis was the pathogen most frequently isolated from subclinical cases in 2 out of 3 CBP. In a further study, Fávero et al. (2015b) found that pack OM and dry density were associated with the concentrations of total bacteria and coliforms. For all CBP included in the study, the concentration of streptococci increased with increasing pack C:N ratio and decreased with increasing pack dry density.

Tomazi et al. (2018) studied the antimicrobial susceptibility of $E$. coli phylogenetic groups isolated from clinical mastitis in different housing systems, including CBP, FS, and outdoor paddocks. No differences in $E$. coli phylogenetic groups or antimicrobial susceptibility were detected among housing systems. Saishu et al. (2015) performed a characterization of Aerococcus viridans isolated from bedding materials and milk samples from cows with clinical mastitis in CBP. The results suggested that bedding materials used, which included processed manure, were possible sources of A. viridans, which caused mastitis infections. Ghielmetti et al. (2017) demonstrated that sawdust and wood chips mixed with organic biodegradable waste are a source of Mycobacteria and may be associated with a higher 
incidence of mastitis in CBP. Because inactivation of Mycobacteria requires more laborious procedures than those for other microorganisms, their maintenance in the environment and in the milking system may be a potential infection source.

Because one of the main objectives of CBP management is to maintain active composting by providing adequate conditions for bacteria to grow in the pack, most reported bedding bacterial counts in CBP are high (ranging from 7.0 to $8.9 \log _{10} \mathrm{cfu} / \mathrm{g}$; Table 3 ). Generally, bedding containing more than $10^{6} \mathrm{cfu}$ of total bacteria/g is believed to increase IMI risk (Jasper, 1980). During composting, temperatures between 45 and $55^{\circ} \mathrm{C}$ have been reported to maximize material degradation, whereas compost temperatures above $55^{\circ} \mathrm{C}$ promote sanitization (Stentiford, 1996). Pack temperatures measured in most CBP (Table 1) indicate that the pack was biologically active, but the temperatures recorded are not sufficient to support either a full composting process or pathogen devitalization.

Most mastitis-causing bacteria thrive in the conditions that have been reported in compost bedding (Black et al., 2014), and thus the CBP environment appears to be hazardous from an udder health standpoint. Nonetheless, udder health traits reported in the literature suggest that adequate udder health can be maintained in CBP. Most authors have highlighted the importance of applying correct pack management procedures. In CBP, keeping the pack dry is paramount in achieving sufficient cow hygiene and decreasing the risk of mastitis. Because of the high bacterial concentrations in bedding, excellent teat preparation procedures in milking have been recommended for dairies with CBP (Janni et al., 2007; Lobeck et al., 2012; Black et al., 2014).

\section{Body Condition}

The results of BCS of cows housed in CBP are summarized in Table 2. Shane et al. (2010) reported that different bedding materials in CBP do not affect BCS. Lobeck et al. (2011) found no differences in BCS among CBP, cross-ventilated FS, and naturally ventilated FS. Seasonally, BCS are higher in the winter than in summer and fall and show no differences between spring and winter. Spring BCS are greater than summer BCS. Multiparous cows have greater BCS than primiparous cows (Lobeck et al., 2011). Ouweltjes and Smolders (2014) reported that the BCS of cows in CBP is in the optimal range for dairy cattle. A recent study also confirmed that cows in CBP can be maintained in the optimal range of BCS and found no differences in body condition between CBP and FS housing systems (Costa et al., 2018).

\section{Culling}

The available data on culling rates in CBP are summarized in Table 2. The herd turnover rate (or culling rate) is expressed as the number of cows culled over 1 yr divided by the mean cow inventory for the same time period (Fetrow et al., 2006).

Barberg et al. (2007b) found that the mean culling rate decreased from $25.4 \%$ to $20.9 \%$ after cows were moved to CBP. Fulwider et al. (2007) reported a lower herd turnover rate for CBP $(20.4 \%)$ than for FS with rubber-filled mattresses $(29.4 \%)$, sand $(25.6 \%)$, and waterbeds $(22.8 \%)$. These results suggest that CBP may reduce the culling rate. In contrast, Lobeck et al. (2011) found a higher herd turnover rate in CBP $(30.1 \%)$ than in cross-ventilated FS $(24.6 \%)$ and naturally ventilated FS (29.0\%), although the differences were not significant. The primary reasons for cow culling in CBP barns were breeding $(24.0 \%)$, mastitis $(20.2 \%)$, and sickness or injury (19.3\%). When the percentages of different reasons for leaving the farm were compared, the housing systems did not differ in mastitis, production, breeding, dairy, sickness or injury, or miscellaneous reasons (Lobeck et al., 2011).

Ouweltjes and Smolders (2014) found a relatively high culling rate in $3 \mathrm{CBP}$. However, the authors reported that in the farm with the highest turnover rate $(37.8 \%)$, most of the cows were still alive $30 \mathrm{~d}$ after culling, thus indicating that those animals were voluntarily sold. On average, in CBP, only $13.8 \%$ of the cows that left the herds were slaughtered within $30 \mathrm{~d}$ after culling (Ouweltjes and Smolders, 2014). Costa et al. (2018) reported a replacement rate of $15.5 \%$ for cows housed in CBP, which was lower than that in FS barns (24.0\%) and FS barns that used CBP only for vulnerable cows (28.0\%). Leso et al. (2019) compared longevity traits in cows housed in CBP and FS. The results showed that cows housed in CBP were older and had higher parities than those housed in FS, whereas no significant differences in herd turnover rate were detected among housing systems.

A high proportion of involuntary culling in the herd indicates poor animal welfare (Ahlman et al., 2011). Although no single turnover rate is optimal for all herds or for all years, research has consistently estimated optimal herd-level culling rates as ranging from 19 to $29 \%$ (Hadley et al., 2006). In a review article, Fetrow et al. (2006) reported that because replacing cows is a major cost of operation, lower annual turnover rates are 
more profitable and optimal turnover rates are $\leq 30 \%$. Currently, culling rates in intensive systems are often above the optimal range and are of concern from both animal well-being and economic points of view (Weigel et al., 2003).

Because CBP has potential to provide a more comfortable environment and improve claw health compared with FS, an improvement in culling rate could be expected in CBP. In addition, improved longevity is one of the most common reasons for building CBP (Barberg et al., 2007b). Most of the herd turnover rates found in CBP are lower than those reported in the literature for FS. Nevertheless, culling data for CBP obtained in different studies are not completely consistent. Differences in culling rates may be explained by the complexity of factors affecting culling rates in different farm scenarios. In addition, some of the inconsistency may have arisen from poor management of the bedded pack. However, given the importance of maintaining adequate culling rates in modern dairy farming, further and more definitive investigation of culling in $\mathrm{CBP}$ is recommended.

\section{Cow Behavior and Reproductive Performance}

Cows exhibit a complex set of behaviors and social interactions. The type of housing can allow or hinder natural behavior, thus affecting animal welfare and, in turn, productivity. An overall goal of loose-housing systems such as CBP is allowing cows freedom of movement. Cows should be able to perform the natural movements associated with getting up and lying down without injury (Fulwider et al., 2007). Haley et al. (2001) reported that dairy cattle spend 8 to $16 \mathrm{~h} / \mathrm{d}$ lying down, thus emphasizing the importance of the lying surface to the animal. Cows provided with softer beds rest longer and stand up and lie down more often than cows on concrete (Haley et al., 2001). The number of times that a cow stands up and lies down each day and the duration of each lying bout, as well as the total lying time, can be used to measure the comfort of the lying surface and housing system (Endres and Barberg, 2007).

Endres and Barberg (2007) first observed the behavior of cows housed in CBP. They reported an overall mean lying time of $9.99 \mathrm{~h} / \mathrm{d}$ (excluding cows with access to pasture). The mean number of lying bouts per day was 11.0, whereas the lying bout duration was 50.8 min. The cows housed in CBP spent a greater amount of time lying at night ( $6.8 \mathrm{~h}$ from 2000 to $0800 \mathrm{~h}$ ) than during the day ( $2.8 \mathrm{~h}$ from 0800 to $2000 \mathrm{~h}$ ). The lying time and walking behavior in CBP were affected by the temperature-humidity index (THI). Cows rested longer and walked less when the THI was $<72(12.7$ $\mathrm{h} / \mathrm{d}$ and 71.6 steps $/ \mathrm{h}$ ) than when the THI was $\geq 72$ $(7.90 \mathrm{~h} / \mathrm{d}$ and $120.8 \mathrm{steps} / \mathrm{h})$. The authors observed that CBP generally provide a soft and cushioned lying surface that allows cows to stand up and lie down without apparent discomfort and that cows are able to move freely on the bedded pack (Endres and Barberg, 2007).

Eckelkamp et al. (2014) investigated behavioral changes in dairy cows transitioning from FS with pasture access to CBP without pasture access. The results showed that cows spent more time lying down after transitioning to CBP (13.1 vs. $9.6 \mathrm{~h} / \mathrm{d}$ ). Cows in CBP also had more lying bouts than cows in FS with pasture access (17.3 vs. 26.7 bouts/d), but the bouts in CBP were shorter (59.7 vs. $69.2 \mathrm{~min}$ ). In addition, in the FS system, lame cows (locomotion score $\geq 3$ ) showed shorter lying times (by $2.1 \mathrm{~h} / \mathrm{d}$ ) than sound cows. However, after transitioning to CBP, no differences in lying time were detected between the lame and sound cows.

Borchers (2018) assessed the sleep-like behavior, time spent feeding, and locomotion scores of lactating Holsteins as affected by housing system. The lying times were significantly higher in CBP (738.2 min) than in FS (606.8 min). Moreover, the cows spent significantly more time performing feeding behaviors in CBP (122.7 min) than in FS (100.4 min). The study also assessed the locomotion scores and found that cows in CBP had a locomotion score of 1.9 and cows housed in FS had a locomotion score of 2.2 .

Ouweltjes and Smolders (2014) measured the time required for cows to lie down in $\mathrm{CBP}$ and FS. Cows housed in FS required more time to lie down $(6.3 \mathrm{~s})$ than those housed in CBP (4.8 s), thus possibly indicating that cows find the bedded pack more comfortable than FS. The time needed to lie down in CBP was also compared with that in SY, and cows in SY laid down more quickly than those in CBP even though both housing systems provide an open resting area with few or no movement restrictions. This result might have been caused by the daily cultivation of the bedded pack, which made it very soft. In fact, when the pack is too soft, cows must pull their legs out from the bedding before lying down, thus increasing the time required to lie down by approximately $1 \mathrm{~s}$ (Ouweltjes and Smolders, 2014). This finding indicates that the bedded pack should be soft to provide a comfortable and healthy surface but should also have adequate load-bearing capacity.

Cows' social interactions in CBP have been observed in a limited number of studies. Social behavior in CBP 
is similar to that observed in cows at pasture (Endres and Barberg, 2007). Ouweltjes and Smolders (2014) also found more frequent positive interactions (allogrooming, or social licking) in herds housed in CBP than in other housing systems. Recently, Pilatti et al. (2019) observed the social behavior of cows in CBP under hot and humid conditions. The multiparous cows exhibited significantly more pushing behavior than the primiparous cows, especially during the hottest hours of the day. For both multiparous and primiparous cows, the agonistic behaviors of pushing, butting, and chasing peaked during the afternoon.

The softer CBP surface provides cows with better footing for estrus behavior expression and thus may positively affect fertility. Barberg et al. (2007b) observed an improvement in reproductive performance in 7 dairies after cows were moved to CBP. The average pregnancy rate increased from $13.2 \%$ to $16.5 \%$ after CBP occupation. Black et al. (2013) also observed an improvement in reproductive parameters between the year before and the second year after moving cows to CBP. The calving interval, number of days to first service, and days open changed from 14.3 to $13.7 \mathrm{mo}$, from 104.1 to $85.3 \mathrm{~d}$, and from 173.0 to $153.4 \mathrm{~d}$, respectively, after cows were moved to CBP. An increase in the percentage of heats was also observed from the year before to the year after CBP occupation ( $42.0 \%$ to $48.7 \%$ ). However, the pregnancy rate and the conception rate remained unaltered after the transition to CBP (Black et al., 2013).

Endres and Barberg (2007), who first studied the behavior of cows in CBP, concluded that $\mathrm{CBP}$ can be an adequate housing system for dairy cows because their observations were not substantially different from those reported in the literature for other types of housing. Other studies have found longer lying times in CBP than in FS, thus indicating improved cow comfort. The open pack area and the soft surface on which cows can stand, walk, and rest in CBP compared with FS systems is more similar to the pasture environment. This similarity decreases behavioral limitations that may result from individual stalls and concrete paving, thereby allowing the expression of natural cattle behavior. Moreover, because heat detection is primarily based on behavior monitoring, $\mathrm{CBP}$ has the potential to improve fertility. However, as with other welfarerelated parameters such as cleanliness, the benefits of CBP housing strictly depend on pack management. If the pack becomes too soft, possibly as a consequence of increased pack moisture or incorrect pack cultivation, cows may sink into the pack, thus deeply limiting cow comfort in CBP and leading to undesired behavioral responses.

\section{Welfare Around Calving}

Little is known about the effects of the CBP housing system on the welfare of cows during the transition period or at calving. Nevertheless, a recent study from Astiz et al. (2014) compared welfare and performance around the time of calving for cows housed in different housing systems. The results showed clear benefits of housing dairy cows during the dry period in CBP systems compared with an SY system based on barley straw. The positive effects of CBP were mainly udder health in early lactation. Cows that spent the dry period in CBP compared with SY had a lower incidence of first mastitis cases (22.1\% vs. $35 \%$ ) and second mastitis cases $(6.8 \%$ vs. $15 \%)$ and a positive trend in SCC (96,100 vs. 139,500 cells $/ \mathrm{mL})$. No differences were detected in pregnancy after first insemination, mortality rate, and the incidence of clinical metritis and endometritis among housing systems (Astiz et al., 2014). The authors concluded that the implementation of CBP systems in dairy farms should be encouraged. Because CBP is frequently indicated as being suitable for cows that are vulnerable or have special needs (Janni et al., 2007), further studies in this field are encouraged.

\section{MILK PRODUCTION AND QUALITY}

The reviewed results regarding milk production and quality in CBP are summarized in Table 4. Barberg et al. (2007b) reported that 8 out of 9 dairies had an increase in 305-d mature equivalent milk production after shifting to CBP. On average, the increase was $955 \mathrm{~kg}$. After shifting from tiestall facilities to CBP, 3 out of 9 dairies also increased milk fat content by $9.8 \%$ and milk protein content by 3.5\%. Similarly, Black et al. (2013) reported a significant increase in milk yield after cows were moved into CBP. Daily milk production increased from before moving into CBP $(29.3 \mathrm{~kg} / \mathrm{d})$ to the second year after barn occupation $(30.7 \mathrm{~kg} / \mathrm{d})$. The rolling herd milk yield average increased from 8,937 to $9,403 \mathrm{~kg}$. However, the effect of the CBP housing system on milk production remains unclear. The authors acknowledged that, beyond the housing system, changes in management probably occurred in the process of moving to the new CBP that could potentially have contributed to the observed increase in milk production (Barberg et al., 2007b; Black et al., 2013). In a direct comparison of different housing systems, Lobeck et al. (2011) found similar 305-d mature equivalent milk production in CBP $(11,154 \mathrm{~kg})$, cross-ventilated FS $(11,536 \mathrm{~kg})$, and naturally ventilated FS $(11,236 \mathrm{~kg})$. Recently, Costa et al. (2018) reported lower milk production in CBP (27.4 $\mathrm{L} /$ cow per day) than in FS (31.3 L/cow per day) and 
Leso et al.: INVITED REVIEW: COMPOST BARNS FOR DAIRY COWS

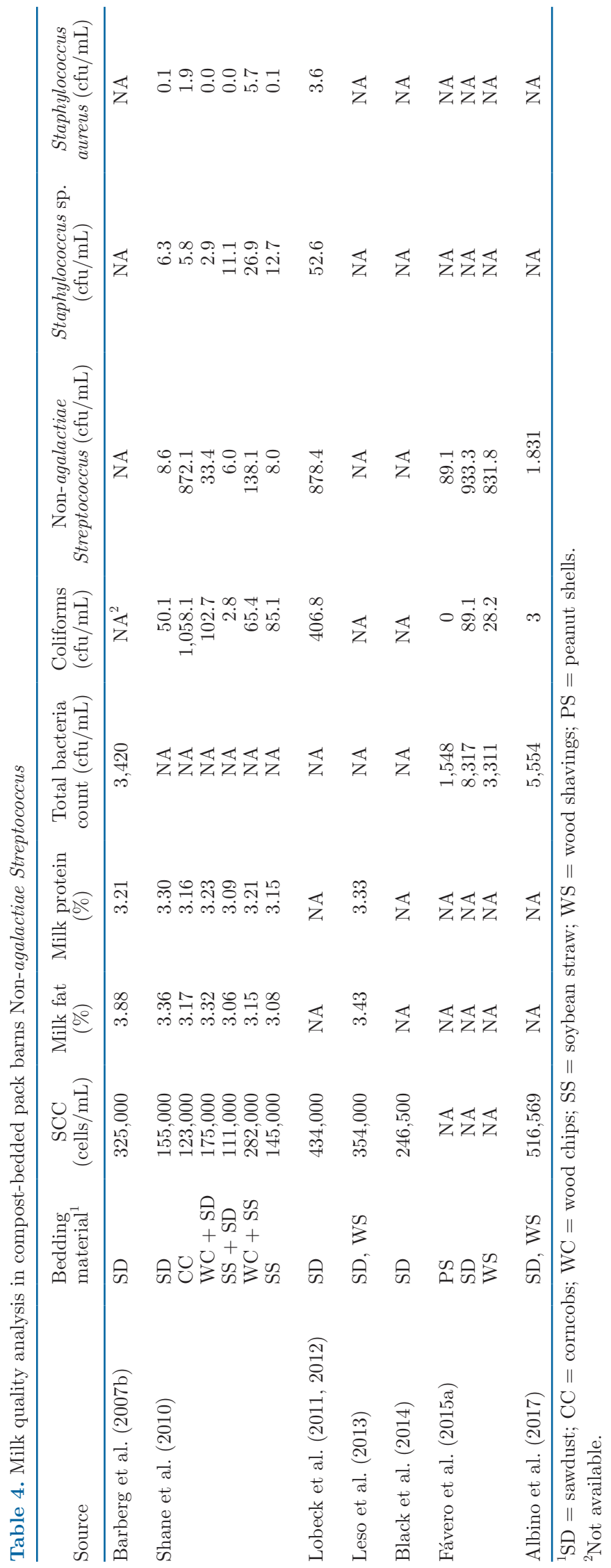


FS that used CBP for only vulnerable cows (30.0 L/ cow per day), although the differences were not statistically significant.

Barberg et al. (2007b) reported that after cows were moved to CBP, 3 out of 7 dairies experienced a decrease in bulk tank SCC (BTSCC) of 90,310 cells/ $\mathrm{mL}$ on average, whereas 1 out of 7 farms registered an increase of 54,600 cells $/ \mathrm{mL}$. Black et al. (2013) also found a decrease in BTSCC from the year before moving cows into CBP (323,700 cells/mL) to the year after $(252,900$ cells $/ \mathrm{mL})$. However, producers who housed only special-needs cows in CBP did not experience any reduction in BTSCC. Eckelkamp et al. (2016a) compared BTSCC CBP and sand-bedded FS and found no significant differences (229,582 vs. 205,131 cells/ $\mathrm{mL}$ ). In the CBP in the study, a significant interaction between pack temperature and barn temperature was detected for BTSCC (Eckelkamp et al., 2016b). With increasing barn and compost temperatures, the BTSCC increased. However, the authors acknowledged that there may have been a confounding effect of barn temperature in this relationship because the pack temperature increased with increasing barn temperature. In addition, the increase in BTSCC observed at high temperatures was likely related to heat stress conditions, which are known to increase SCC.

Milk production and quality in CBP have been measured in several studies. In dairy operations, milk yield can be affected by several factors; therefore, quantifying the effect of housing system alone is challenging. The results in the literature indicate that high levels of milk production are possible in CBP. Furthermore, because $\mathrm{CBP}$ has the potential to improve cow comfort, greater milk production than that in other housing systems such as FS might be expected. However, a comparison of milk yield of cows housed in CBP and FS did not show a clear difference. An increase in milk fat and protein content after moving cows to CBP was observed in one study (Barberg et al., 2007b). The authors highlighted that these observations on milk components deserve further and more definitive investigation, but to our knowledge no studies have focused on the effects of CBP housing on milk fat and protein content to date.

As discussed for udder health, the high pack bacteria concentrations measured in CBP may be an area of concern for udder health and milk quality. However, results on BTSCC and TBC in milk indicate that adequate milk quality can be achieved in CBP. Lobeck et al. (2012) compared milk bacterial counts in CBP, naturally ventilated FS, and low-profile cross-ventilated FS and found no differences among the housing systems. Effective management of the bedded pack and excellent cow preparation procedures at milking time remain essential for producers operating CBP. The bedding should be kept as dry and clean as possible to avoid teat and milk contamination. In addition, the choice of bedding material may affect milk quality in CBP. Recent research has highlighted that some bedding materials used in CBP (sawdust and wood chips mixed with organic biodegradable waste) may be a source of Mycobacteria that can be transferred to milk, thus potentially posing a health risk to consumers of raw milk (Ghielmetti et al., 2017).

In recent years, research in the Netherlands has indicated that the use of green waste household compost and composting wood chips as bedding for dairy cows can cause milk contamination by thermophilic aerobic spore-forming bacteria (TAS), especially by a subpopulation of bacteria that produces extremely heat-resistant spores (XTAS). Spores produced by TAS and XTAS can survive standard milk sterilization processes, thus decreasing the shelf life of some dairy products (Driehuis et al., 2014). For this reason, in 2015, a major Dutch dairy company decided to forbid the use of household compost as bedding for dairy cows in both CBP and FS, whereas the use of composting wood chips and other bedding materials remains permitted (Galama et al., 2014).

Driehuis et al. (2014) investigated the presence of TAS and XTAS in various types of bedding materials and in milk from CBP. Spores of both TAS and XTAS were detected in bedding materials, whereas only TAS were found in milk. The concentrations of XTAS could not be determined in tank milk because the concentrations were below the limit of detection. High concentrations of TAS and XTAS spores were detected in household waste compost and composting wood chips. From the bedded pack, TAS and XTAS bacteria can contaminate cow teats. Although they are not believed to produce IMI in cows, TAS and XTAS from contaminated udders are transferred to milk (Driehuis et al., 2012). Owing to the high concentration of spores in household waste compost and composting wood chips, teat cleaning operations have been shown to be insufficient to prevent milk contamination (Driehuis et al., 2014).

The mean concentrations of TAS and XTAS in household waste compost were 6.9 and $4.1 \log _{10} \mathrm{cfu} / \mathrm{g}$, respectively. Aeribacillus and Geobacillus spp. were the predominant XTAS species, whereas Bacillus thermoamylovorans was the predominant TAS (Driehuis et al., 2014). In household waste compost, the XTAS spore levels were, on average, 1,000 times higher than those in sawdust and straw bedding. Spores of TAS and XTAS are likely to be produced during the composting process of municipal biowaste. Generally, TAS and XTAS spore levels were lower in composting wood chips than in household compost obtained in composting plants from organic municipal solid waste. Fresh wood chips 
did not always appear to be a relevant source of these bacteria, but, because in CBP the bedded pack reaches relatively high temperatures, TAS and XTAS spores may be produced at the farm level. Driehuis et al. (2014) reported that concentrations of TAS and XTAS in CBP with wood chips as bedding likely depend on the intensity of the composting process in the pack, but further research is needed to clarify this relationship.

Other bedding materials such as sawdust, straw, and separate manure solids have shown very limited concentration of TAS and XTAS compared with household waste compost and composting wood chips (Galama et al., 2014). For this reason, in the past few years many producers in the Netherlands have begun using wheat straw in CBP instead of household waste compost. In a recent study, milk quality and the performance and welfare of cows housed in CBP using waste compost, composting wood chips, and straw were compared. In CBP using straw, lower concentrations of TAS and XTAS were found in milk. Furthermore, cows housed on straw bedding had the lowest SCC (Galama et al., 2014), thus indicating that straw can provide a viable alternative to compost and wood materials in CBP.

Borchers (2018) tested for the presence of TAS and XTAS in beds in CBP $(\mathrm{n}=10)$ and FS $(\mathrm{n}=10)$. The study also assessed their presence on teats both pre- and posttreatment and their presence in bulk tank milk. The counts of TAS and XTAS in beds were significantly higher for CBP than for FS, but bulk tank milk showed no significant differences between groups. This result was attributed to good teat preparation of cows before milking.

\section{BEDDED PACK CHARACTERISTICS AND MANURE QUALITY}

Bedded pack from CBP has been analyzed in several studies. The reviewed results of pack chemical analyses are summarized in Table 5.

In contrast to FS housing systems, in CBP, feces and urine produced by the cows over the bedded area are absorbed or mixed in the pack and can be handled as solid manure. This aspect is often perceived as an advantage and is one of the reasons for producers to build CBP (Leso et al., 2013). Typically, in CBP, the pack is renovated every 6 to 12 mo; therefore, bedded pack can provide manure storage for relatively long periods. Solid manure can be used for direct land application, stored for future use, or further composted to improve manure quality and stability (Bewley et al., 2017). The amount of solid manure produced in CBP depends on several factors, including the amount and type of bedding used, area per cow, and composting process.

Table 5. Chemical analysis of bedding material from compost-bedded pack barns

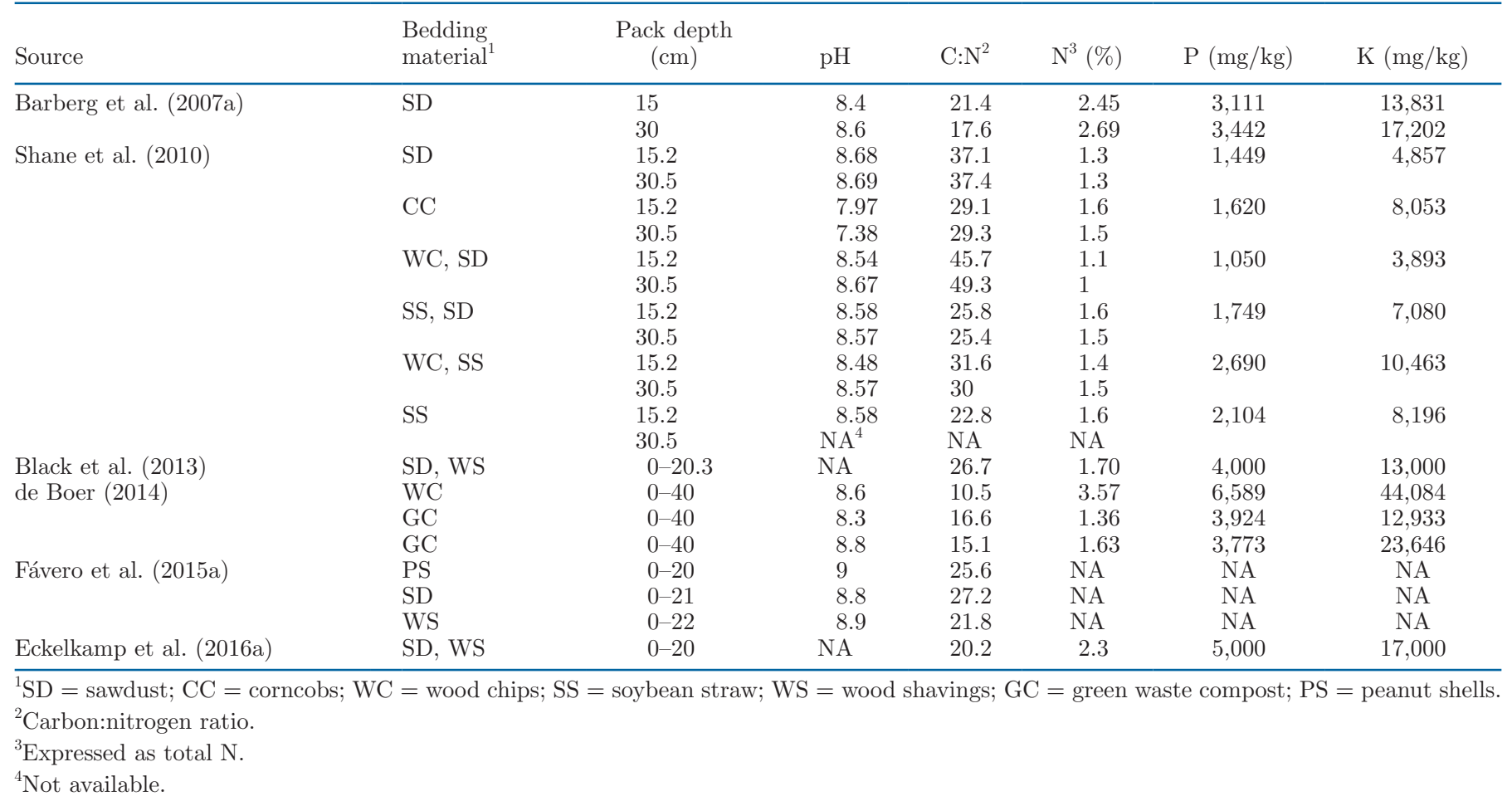


In CBP with a scraped (or slatted) feed alley, liquid manure is also produced, which must be handled in dedicated facilities. Producers with CBP have estimated that the concrete feed alley collects 20 to $25 \%$ of urine and feces produced (Barberg et al., 2007a). Other studies, however, have estimated that approximately $50 \%$ of the excreta produced by the cows are voided into the feed alley (Smits and Aarnink, 2009).

The mean $\mathrm{pH}$ level measured in various $\mathrm{CBP}$ with different bedding materials ranges from 7.4 to 9.0 (Table 5), which is within or above the recommended $\mathrm{pH}$ range for composting of 6.5 to 8.0 (FAO, 2003). The $\mathrm{C}: \mathrm{N}$ ratio shows a wide range of variation from 10.5 to 49.3 (Table 5). Wood materials such as sawdust and wood chips are expected to have a higher C:N ratio (Shane et al., 2010). However, only a few studies have reported $\mathrm{C}: \mathrm{N}$ ratios in $\mathrm{CBP}$ within the optimal range for composting (25:1 to 30:1; FAO, 2003). The mean pack moisture tends to remain in the optimal range for this housing system (from 40\% to 60-65\%; Bewley et al., 2012; Table 1), thus indicating that, although most producers are able to keep the pack sufficiently dry, maintaining an optimal C:N ratio in $\mathrm{CBP}$ can pose some challenges.

Nutrient analysis of bedded pack from CBP has shown that the $\mathrm{N}, \mathrm{P}$, and $\mathrm{K}$ content ranges from $1 \%$ to $3.57 \%$, from 1,050 to $6,589 \mathrm{mg} / \mathrm{kg}$, and from 3,893 to $44,084 \mathrm{mg} / \mathrm{kg}$, respectively (Table 5 ). Research has revealed that the composition, $\mathrm{C}$ decomposability, and $\mathrm{N}$ mineralization rate of manure from CBP are largely similar to those of regular green waste compost. Over the long term, the use of manure from CBP as fertilizer can result in considerably higher amounts of soil OM and larger accumulation of organic $\mathrm{N}$ than liquid cattle manure. However, manure from CBP is not suitable as a short-term $\mathrm{N}$ fertilizer due to its low content of mineral $\mathrm{N}$ and slow $\mathrm{N}$ mineralization rate (de Boer, 2014). The $\mathrm{N}$ availability to the soil might plausibly be improved by continued manure composting after removal from the CBP (Black et al., 2013; de Boer, 2014).

Compared with liquid cattle manure, bedded-pack compost is scarcely suitable as a nitrogen fertilizer in the short term but is suitable as a fertilizer in the long term. Consequently, a transition from FS to CBP with production of compost also requires a transition in farmers' views on fertilization and fertilization strategies (de Boer, 2014). Bedded-pack compost decomposes considerably more slowly than liquid cattle manure. When the same amount of OM is applied, bedded-pack compost contributes considerably more to the build-up of soil $\mathrm{OM}$ and soil fertility than liquid cattle manure. For CBP with wood chip composting, approximately 6 times more OM has been estimated to remain in the soil after a period of $10 \mathrm{yr}$ compared with the original liquid manure produced (de Boer, 2014). Consequently, bedded-pack compost is highly suitable to increase the soil OM content and soil fertility of farmland.

\section{GASEOUS EMISSIONS}

During the composting process, the $\mathrm{C}: \mathrm{N}$ ratio and $\mathrm{pH}$ affect ammonia volatilization. A C:N ratio below 25:1 may increase ammonia emissions (Rosen et al., 2000). The $\mathrm{pH}$ level controls the equilibrium between ammonium ions and ammonia. At high $\mathrm{pH}$, this equilibrium is displaced toward ammonia, and its volatilization may consequently be facilitated (Jeppsson, 1999). The high $\mathrm{pH}$ and the relatively low $\mathrm{C}: \mathrm{N}$ ratio found in CBP (Table 5) suggest that pack conditions are conducive to $\mathrm{NH}_{3}$ loss (Shane et al., 2010). Only a few studies have focused on gaseous emissions in CBP, almost all of which have been carried out in northern Europe, where the laws on emissions in agriculture are more restrictive than those in most countries.

Alvarado-Raya et al. (2017) studied the effects of moisture content, $\mathrm{pH}$, and compost particle size on the $\mathrm{CH}_{4}$ and $\mathrm{CO}_{2}$ emission rates from compost particles collected from the CBP tillage layer (aerobic zone). Both the $\mathrm{CH}_{4}$ and $\mathrm{CO}_{2}$ emission rates increased as the compost particle size increased from $1.19 \mathrm{~mm}$ sieved diameter to $>12.5 \mathrm{~mm}$ sieved diameter. The particle $\mathrm{pH}$ also affected the $\mathrm{CH}_{4}$ and $\mathrm{CO}_{2}$ emission rates. Tests have been conducted on collected compost particles with the initial pH set at $5,6,7,8,9$, and 10 . The $\mathrm{CH}_{4}$ emission rate increased with $\mathrm{pH}$ up to 9.0 , whereas the $\mathrm{CO}_{2}$ emission rate was maximum in the $\mathrm{pH}$ range of 6 to 7 . Compost moisture content of $41,48,51,57$, and $67 \%$ was also evaluated for $\mathrm{CH}_{4}$ and $\mathrm{CO}_{2}$ emission rates. Only a moisture content of $41 \%$ affected the $\mathrm{CH}_{4}$ emission rate, which was $<1 \%$ of the $\mathrm{CH}_{4}$ emission rates at the higher moisture contents, whereas the $\mathrm{CO}_{2}$ emission rate increased significantly with moisture content. Maia et al. (2012) also found that the moisture content of compost affected $\mathrm{N}_{2} \mathrm{O}$ emission rates. A compost moisture content above $43 \%$ was found to have the highest $\mathrm{N}_{2} \mathrm{O}$ emission rates. Wolf (2017) measured the compost bed emission rates of $\mathrm{N}_{2} \mathrm{O}, \mathrm{CH}_{4}$, and $\mathrm{CO}_{2}$ in $\mathrm{CBP}$. The bed temperature at $20-\mathrm{cm}$ depth was $48.5^{\circ} \mathrm{C}$, with a bed moisture content of $49 \%$. Emission measurements were collected at 20,60, and 100 min after tillage, and the emission rates $\left(\mathrm{g} / \mathrm{m}^{2}\right.$ per hour) decreased with time: $\mathrm{N}_{2} \mathrm{O}$ (0.0031, NS, NS), $\mathrm{CH}_{4}(0.21,0.013,0.082)$, and $\mathrm{CO}_{2}(100.2,24.1,26.4)$.

van Dooren et al. (2011) studied the emission of $\mathrm{NH}_{3}, \mathrm{CH}_{4}$, and $\mathrm{CO}_{2}$ in $\mathrm{CBP}$ bedded with 3 materials: sand, composting wood chips, and a mixture of peat and reeds. On average, the emissions from the surface of the pack bedded with sand for $\mathrm{NH}_{3}, \mathrm{CH}_{4}$, and $\mathrm{CO}_{2}$ 
were $415 \mathrm{mg} / \mathrm{m}^{2}$ per hour, $0.04 \mathrm{~g} / \mathrm{m}^{2}$ per hour, and 22 $\mathrm{g} / \mathrm{m}^{2}$ per hour, respectively. In a CBP bedded with compost, the emissions of $\mathrm{NH}_{3}, \mathrm{CH}_{4}$, and $\mathrm{CO}_{2}$ were $227 \mathrm{mg} / \mathrm{m}^{2}$ per hour, $1.4 \mathrm{~g} / \mathrm{m}^{2}$ per hour, and $101 \mathrm{~g} /$ $\mathrm{m}^{2}$ per hour, respectively. The pack bedded with peat and reeds emitted $182 \mathrm{mg}$ of $\mathrm{NH}_{3} / \mathrm{m}^{2}$ per hour, $0.6 \mathrm{~g}$ of $\mathrm{CH}_{4} / \mathrm{m}^{2}$ per hour, and $18 \mathrm{~g}$ of $\mathrm{CO}_{2} / \mathrm{m}^{2}$ per hour (van Dooren et al., 2011). Sand bedding had the highest ammonia emissions, whereas compost emitted more $\mathrm{CH}_{4}$ and $\mathrm{CO}_{2}$ than other materials.

van Dooren et al. (2011) also compared ammonia emissions in CBP bedded with the materials previously described and in an FS with a fully slatted floor. All CBP examined had a slatted feeding alley. Regardless of the housing system, ammonia emissions from the areas with a slatted floor (with slurry pit below) were $1,200 \mathrm{mg} / \mathrm{m}^{2}$ per hour, and therefore the $\mathrm{NH}_{3}$ emissions per square meter of slatted floor were much higher than those with bedded pack. Nevertheless, because in CBP the area allotment per cow was higher than that in FS, the total ammonia emissions per cow in CBP were similar to or even higher than those in FS depending on the bedding material. In CBP bedded with sand, the total $\mathrm{NH}_{3}$ emissions per cow (bedded area + slatted floor) were $80 \%$ higher than those in FS, whereas in CBP bedded with organic materials (compost or peat and reeds) the total ammonia emissions were only 5 to $10 \%$ higher (Galama et al., 2011). These results indicated that the biological processes in organic bedded packs might reduce gaseous nitrogen losses, probably because bacteria use part of the nitrogen contained in cattle excreta during the degradation of OM.

In a very recent study (van Dooren et al., 2019), emissions of ammonia and greenhouse gases were measured in 3 commercial farms and in 1 experimental farm. The ammonia emissions per cow in CBP were $30 \%$ lower than in conventional FS with a slatted floor. This finding suggests that by optimizing bedding management (which probably occurred in the country in recent years), it is possible to reduce the emission of ammonia despite the larger emitting surface than that in FS.

Another study from de Boer (2014) focused on nitrogen balance in $2 \mathrm{CBP}$ and $1 \mathrm{FS}$. The 2 types of $\mathrm{CBP}$ considered were bedded with green waste compost or composting wood chips; both had a slatted feeding alley, whereas the FS barn had a fully slatted floor. In this study, gaseous nitrogen losses in the barn as well as those produced during land application of manure were examined. The percentages of nitrogen lost over the total nitrogen excreted by the cows were 19.0, 43.9, and $8.9 \%$ for the CBP with composting wood chips, CBP with green waste compost, and FS, respectively (de Boer, 2014). In the CBP, most of the nitrogen was emitted from the bedded pack rather than from the slatted feeding alley. During land application of manure produced in CBP with composting wood chips, CBP with green waste compost, and FS, 4.8, 3.9, and $8.7 \%$ of the total nitrogen excreted was emitted, respectively (de Boer, 2014). Nitrogen losses in this phase for manure produced in CBP were entirely caused by the liquid manure collected in the slatted alleys, whereas emissions derived by land application of bedded pack materials were negligible. Although nitrogen losses in land application of manure were lower for CBP, the total nitrogen loss was higher for CBP with green waste compost (43.9\%) and CBP with composting wood chips $(23.8 \%)$ than for FS (17.6\%). de Boer (2014) argued that gaseous nitrogen losses in CBP mainly consist of $\mathrm{NH}_{3}$, nitrous oxide $\left(\mathrm{N}_{2} \mathrm{O}\right)$, and nitrogen gas $\left(\mathrm{N}_{2}\right)$, but no direct measurements were collected for $\mathrm{N}_{2} \mathrm{O}$ and $\mathrm{N}_{2}$.

Lobeck et al. (2012) measured aerial concentrations of $\mathrm{NH}_{3}$ and hydrogen sulfide $\left(\mathrm{H}_{2} \mathrm{~S}\right)$ in $\mathrm{CBP}$, low-profile cross-ventilated FS, and naturally ventilated FS. The ammonia concentrations were $3.9 \mathrm{ppm}$ in CBP, 5.2 ppm in cross-ventilated FS, and $3.3 \mathrm{ppm}$ in naturally ventilated FS. The cross-ventilated barns had higher ammonia concentrations than CBP and naturally ventilated FS, whereas CBP and naturally ventilated FS did not differ (Lobeck et al., 2012). The hydrogen sulfide aerial concentrations were 13,32 , and $17 \mathrm{ppb}$ in CBP, cross-ventilated FS, and naturally ventilated FS, respectively. Cross-ventilated FS had higher $\mathrm{H}_{2} \mathrm{~S}$ concentrations than the other housing systems, and no differences were observed between CBP and naturally ventilated FS (Lobeck et al., 2012). In all housing systems studied by Lobeck et al. (2012), the highest concentration of $\mathrm{NH}_{3}$ was measured in summer, whereas $\mathrm{H}_{2} \mathrm{~S}$ was higher during winter.

\section{ECONOMICS}

Authors from the United States have reported that CBP have lower investment costs than FS because of the lower concrete requirement and the lack of stall hardware (Barberg et al., 2007a; Janni et al., 2007). However, some states in the United States (and most countries in the European Union) require a concrete base under the pack to reduce nutrient seepage, and, compared with FS, more area per cow is necessary to maintain adequate hygienic conditions in CBP. The necessity of a concrete base can be justified for stacked manure storage where drainage is anticipated from the high-moisture-content manure solids regardless of whether the storage areas are under a roof (NRCS, 1999).

Barberg et al. (2007a) reported building costs per cow place for $\mathrm{CBP}$ in Minnesota ranging from $\$ 625$ 
to $\$ 1,750$. The average cost per cow on the basis of a uniform space allowance of $7.4 \mathrm{~m}^{2}$ per cow was $\$ 1,200$. Petzen et al. (2009) calculated the construction costs of dairy barns and found that the cost per cow place in CBP was similar to that in FS. The cost per cow place in $\mathrm{CBP}$ decreased with decreasing area per cow (in the resting area) from $\$ 2,489$ per cow at $9.3 \mathrm{~m}^{2} /$ cow to $\$ 1,988$ per cow at $7.4 \mathrm{~m}^{2} /$ cow.

Black et al. (2013) studied CBP in Kentucky and found a cost per cow of $\$ 1,051$ (assuming $9.3 \mathrm{~m}^{2} / \mathrm{cow}$ ). Producers spent $\$ 78.77 / \mathrm{m}^{2}$ of barn area, including the feed alley. Comparing the construction costs of CBP and FS, Black et al. (2013) showed that CBP cost was $\$ 900$ or $46 \%$ less per cow than that of FS with mattresses and $\$ 750$ or $42 \%$ less per cow than that of FS with sand bedding. The lower initial cost may be an important factor in making CBP a desirable housing option for dairy producers in the United States.

Higher building costs for CBP have been reported in Dutch studies. Galama et al. (2011) calculated building costs of $€ 3,138$ per cow place for CBP with compost bedding and $€ 2,580$ per cow place for CBP bedded with composting wood chips (including feeding alley and manure storage facilities). Compared with FS (with a fully slatted floor), the cost per cow place for CBP with compost bedding was $€ 128$ higher, whereas CBP with composting wood chips was $€ 430$ per cow cheaper. However, CBP construction costs were calculated by assuming space allotments in the resting area of $15 \mathrm{~m}^{2} /$ cow in CBP with compost bedding and $8 \mathrm{~m}^{2} /$ cow in CBP bedded with composting wood chips (Galama et al., 2011), even though more recent studies have indicated that 12 to $15 \mathrm{~m}^{2}$ per cow is necessary in CBP under Dutch climate conditions (Galama, 2014).

Galama et al. (2015) analyzed the construction costs of the 2 main types of CBP in the Netherlands, assuming $15 \mathrm{~m}^{2} /$ cow in the resting area for CBP with either green waste compost bedding or composting wood chips. The results showed higher building costs for CBP with composting wood chips $(€ 4,309$ per cow place) than compost (€3,709 per cow place). Moreover, the cost for compost-bedded CBP was similar to that estimated for FS with a full slatted floor $(€ 3,667$ per cow place). The higher construction cost for CBP bedded with composting wood chips was due to the forced aeration system installed in the floor below the pack (Galama et al., 2014). In addition, this system would have greater utilization of electric energy, an important component of the cost of milk production (Lopes et al., 2015).

Woodford et al. (2018) investigated initial investment for CBP in New Zealand and found that the overall cost can vary between $\mathrm{NZ} \$ 1,500$ and $\mathrm{NZ} \$ 3,000(\mathrm{NZ} \$ 1=$ US\$0.63) per cow, which is lower than the typical costs of FS barns in the same area. Brito (2016) found that construction costs for CBP in Brazil were $\mathrm{R} \$ 4,275.69$ $(\mathrm{R} \$ 1=\mathrm{US} \$ 0.24)$. More recently, Silva et al. (2019) analyzed capital invested in Brazilian dairy farms and showed that farms with CBP have a lower percentage of total capital invested in farm facilities than those with FS (55.31\% vs. $58.79 \%)$. In the same study, the mean construction costs for CBP and FS were reported to be $\mathrm{R} \$ 3,501.10$ and $\mathrm{R} \$ 3,763.11$ per cow place, respectively.

Many authors in different countries have noted that the cost and availability of bedding can limit the use of CBP (Shane et al., 2010). The high cost of bedding in CBP is mentioned by producers as the main disadvantage of this housing system (Barberg et al., 2007b; Leso et al., 2013; Woodford et al., 2018). In Minnesota $\mathrm{CBP}$, the cost for bedding (dry fine wood shavings or sawdust) has been found to range from $\$ 0.35$ to $\$ 0.85 /$ cow per day (Barberg et al., 2007b). Janni et al. (2007) reported that in CBP with a space allotment of $7.4 \mathrm{~m}^{2} /$ cow, $19.6 \mathrm{~m}^{3} /$ cow of dry fine sawdust was consumed, thus resulting in a cost of $\$ 181 /$ cow per year or $\$ 0.50 /$ cow per day.

Black et al. (2013) examined bedding costs in Kentucky CBP. Producers used different materials, including kiln-dried sawdust or shavings, green sawdust or shavings, and a mixture of kiln-dried sawdust or shavings and green sawdust or shavings or soy hulls. The mixture of dry and green wood materials or soy hulls was the most expensive $\left(\$ 9.45 / \mathrm{m}^{3}\right)$ followed by kiln-dried sawdust or shavings $\left(\$ 8.19 / \mathrm{m}^{3}\right)$ and green sawdust or shavings $\left(\$ 3.30 / \mathrm{m}^{3}\right)$. On average, bedding utilization ranged from $0.07 \mathrm{~m}^{3} / \mathrm{cow}$ per day for the mixture of dry and green wood materials or soy hulls and for green sawdust or shavings to $0.05 \mathrm{~m}^{3} /$ cow per day for kiln-dried sawdust or shavings. The mean costs of bedding were found to be $0.35,0.26$, and $\$ 0.70 /$ cow per day for kiln-dried sawdust or shavings, green sawdust or shavings, and a mixture of kiln-dried sawdust or shavings and green sawdust or shavings or soy hulls (Black et al., 2013).

Shane et al. (2010) tested different bedding materials in CBP and found bedding utilization of 8.8, 15.2, 14.8, $11.1,26.7$, and $16.9 \mathrm{~kg} / \mathrm{cow}$ per day for sawdust, corn cobs, a mixture of wood chips and sawdust (2:1 volume: volume ratio), a mixture of soybean straw and sawdust (2:1 volume:volume ratio), a mixture of wood chips and soybean straw (2:1 volume:volume ratio), and soybean straw, respectively. The cost of bedding materials was $\$ 0.12, \$ 0.04, \$ 0.02$, and $\$ 0.09$ per kilogram for corn cobs, sawdust, wood chips, and soybean straw, respectively. The cost of bedding per cow per day was $\$ 0.35$, $\$ 1.90, \$ 0.45, \$ 0.85, \$ 0.60$, and $\$ 1.45$ for sawdust, corn cobs, a mixture of wood chips and sawdust, a mixture of soybean straw and sawdust, a mixture of wood chips 
and soybean straw, and soybean straw, respectively (Shane et al., 2010).

Except for corn cobs and soybean straw, the costs of bedding per cow reported by Shane et al. (2010) are similar to those found by Barberg et al. (2007b), Janni et al. (2007), and Black et al. (2013). These results indicate that, in the Upper Midwest United States, the cost of bedding in CBP using wood materials (and a space allotment in the resting area of 6.9 to $12.0 \mathrm{~m}^{2} /$ cow) would be between $\$ 0.26$ and $\$ 0.85 /$ cow per day. Black et al. (2013) compared bedding costs in CBP and FS and found lower costs of $\$ 0.18 /$ cow per day for sand-bedded FS and $\$ 0.13 /$ cow per day for mattressbased FS.

Galama et al. (2011) estimated the costs of bedding in 2 types of $\mathrm{CBP}$ in the Netherlands. The bedding costs were $€ 0.21 /$ cow per day for CBP bedded with compost and $€ 0.11 /$ cow per day for CBP with composting wood chips and forced aeration. In this study, a cost of $€ 10 / \mathrm{m}^{3}$ for green waste compost and of $€ 5 / \mathrm{m}^{3}$ for wood chips was assumed. More recently, Galama (2014) measured bedding utilization and costs in 3 existing Dutch CBP. The results highlighted bedding utilization of $13.7 \mathrm{~kg} /$ cow per day in CBP bedded with composting wood chips and from 22.8 to $42.8 \mathrm{~kg} /$ cow per day in compost-bedded CBP. The cost of wood chips ranged from $€ 0.035$ to $€ 0.045 / \mathrm{kg}$, whereas the cost of compost ranged from $€ 0.008$ to $€ 0.014 / \mathrm{kg}$. The costs of bedding per cow and per day varied from €0.48 to €0.62 for CBP bedded with composting wood chips and from $€ 0.18$ to $€ 0.60$ for compost-bedded CBP (Galama, 2014). The most recent data available on bedding costs in Dutch CBP indicate average annual costs of €168/ cow for CBP with composting wood chips and forced aeration and $€ 120 /$ cow for CBP bedded with household waste compost (Galama et al., 2015). In all Dutch studies of bedding utilization and economics in different housing systems, CBP has been found to have higher bedding utilization and costs than FS (Galama et al., 2011, 2014).

Leso et al. (2013) found an average bedding utilization of $8.2 \mathrm{~m}^{3} /$ cow per year in Italian CBP. Considering an average cost for dry sawdust of $€ 18 / \mathrm{m}^{3}$, the annual bedding cost was €148/cow. Brito (2016), in Brazilian CBP, observed values from $\mathrm{R} \$ 30.00$ to $\mathrm{R} \$ 38.00$ spent on bedding per animal housed per month. Silva et al. (2019) compared the contribution of bedding cost with the total production cost of milk in Brazil and found that CBP farms had a higher bedding cost contribution than FS farms ( $1.49 \%$ vs. $0.42 \%)$.

Although the CBP housing system is likely to have higher bedding costs than FS, the potential improvements in cow health, such as lower lameness prevalence, may offset these costs. The availability and cost of bedding materials are regarded as the main limits to the adoption of the CBP housing system. Wood-based materials, which are commonly used in CBP, are increasingly in demand on the market of renewable energy sources and will probably become scarcer in coming years. Further research should therefore focus on identifying alternative sources of bedding materials to be used in CBP. Inexpensive and largely available materials such as organic by-products or even waste materials (where allowed by the law) should be prioritized. When evaluating alternative materials, particular attention must be paid to microbiological safety and potential effects on milk quality.

\section{CONCLUSIONS}

The studies reviewed indicate that $\mathrm{CBP}$ can provide a viable alternative to $\mathrm{FS}$ and $\mathrm{SY}$ for housing dairy cows. The main benefits of this system include improved cow comfort, better foot and leg health, more natural animal behavior, and improved manure quality. The results with CBP, however, strictly depend on pack management. Producers should pay particular attention to maintaining adequate pack moisture, which appears to be the most important factor in CBP management. High pack moisture is associated with increased prevalence of dirty cows, higher mastitis risk, reduced cow comfort, and higher gaseous emissions. In temperate climates, maintaining adequately dry bedding during the winter may pose some challenges. Because cold and humid weather limits evaporation of water from the pack, large amounts of dry bedding may be necessary to absorb excessive pack moisture. Although several studies have focused on the health and behavior of cows housed in CBP, some research questions about animal welfare remain to be fully addressed. Improved longevity is one of the most common reasons reported by producers for adoption of the CBP system. However, several studies have evaluated the effects of CBP on cow longevity, and the results are not completely consistent. Some doubts also remain regarding the risk of mastitis in CBP. Although most authors recommend maintaining a high pack temperature to promote bedding sanitization, microbiological analyses indicate that most mastitis-causing bacteria can grow at the temperatures recorded in composting packs. Finally, research on the economic sustainability of the CBP system remains sparse. Most economic analyses indicate that CBP has higher bedding costs than FS systems, but the economic value of welfare improvement that can be achieved with CBP remains to be quantified. 


\section{ACKNOWLEDGMENTS}

The authors acknowledge funding provided by ERANet Cofund SusAn (grant no. 696231) through the research project FreeWalk. The authors also thank Andreas Zentner (LFZ Raumberg-Gumpenstein, Austria) for sharing information about the development of compost-bedded pack barns in Austria (LFZ Raumberg-Gumpenstein, Irdning-Donnersbachtal, Austria). The authors have not stated any conflicts of interest.

\section{REFERENCES}

Ahlman, T., B. Berglund, L. Rydhmer, and E. Strandberg. 2011. Culling reasons in organic and conventional dairy herds and genotype by environment interaction for longevity. J. Dairy Sci. 94:15681575. https://doi.org/10.3168/jds.2010-3483.

Alban, L. 1995. Lameness in Danish dairy cows; Frequency and possible risk factors. Prev. Vet. Med. 22:213-225. https://doi.org/10 .1016/0167-5877(94)00411-B.

Albino, R. L., J. L. Taraba, M. I. Marcondes, E. A. Eckelkamp, and J. M. Bewley. 2017. Comparison of bacterial populations in bedding material, on teat ends, and in milk of cows housed in compost bedded pack barns. Anim. Prod. Sci. 58:1686-1691. https://doi.org/ 10.1071/AN16308.

Albright, J. C. 1995. Flooring in dairy cattle facilities. Pages 168-182 Proc. International Conference on Animal Behavior and the Design of Livestock and Poultry Systems, Indianapolis, IN. Northeast Regional Agricultural Engineering Service, Cooperative Extension, Ithaca, NY.

Alvarado-Raya, H. E., J. L. Taraba, and M. S. Coyne. 2017. Factores regulatorios para las emisiones de metano y dióxido de carbono a partir de compostas. Pages 459-460 in V Congreso Internacional y XIX Congreso Nacional de Ciencias Agronómicas, Estado de México, México. Universidad Autónoma Chapingo, Chapingo, Mexico.

Astiz, S., F. Sebastian, O. Fargas, M. Fernández, and E. Calvet. 2014. Enhanced udder health and milk yield of dairy cattle on compost bedding systems during the dry period: A comparative study. Livest. Sci. 159:161-164. https://doi.org/10.1016/j.livsci.2013.10.028.

Barberg, A. E., M. I. Endres, and K. A. Janni. 2007a. Compost dairy barns in Minnesota: A descriptive study. Appl. Eng. Agric. 23:231238. https://doi.org/10.13031/2013.22606.

Barberg, A. E., M. I. Endres, J. A. Salfer, and J. K. Reneau. 2007b. Performance and welfare of dairy cows in an alternative housing system in Minnesota. J. Dairy Sci. 90:1575-1583. https://doi.org/ 10.3168/jds.S0022-0302(07)71643-0.

Bernardi, F., J. Fregonesi, C. Winckler, D. M. Veira, M. A. G. von Keyserlingk, and D. M. Weary. 2009. The stall-design paradox: Neck rails increase lameness but improve udder and stall hygiene. J. Dairy Sci. 92:3074-3080. https://doi.org/10.3168/jds.2008-1166.

Bewley, J., R. W. Palmer, and D. B. Jackson-Smith. 2001. An overview of experiences of Wisconsin dairy farmers who modernized their operations. J. Dairy Sci. 84:717-729. https://doi.org/10.3168/jds .S0022-0302(01)74526-2.

Bewley, J. M., L. M. Robertson, and E. A. Eckelkamp. 2017. A 100year review: Lactating dairy cattle housing management. J. Dairy Sci. 100:10418-10431. https://doi.org/10.3168/jds.2017-13251.

Bewley, J. M., J. L. Taraba, G. B. Day, and R. A. Black. 2012. Compost bedded pack barn design features and management considerations. Cooperative extension publ. ID 206. University of Kentucky College of Agriculture, Lexington, KY.

Bewley, J. M., J. L. Taraba, D. McFarland, P. Garrett, R. Graves, B. Holmes, D. Kammel, J. Porter, J. Tyson, S. Weeks, and P. Wright. 2013. Guidelines for Managing Compost Bedded-Pack Barns. The Dairy Practices Council, Ritchboro, PA.

Biemans, F., P. Bijma, N. M. Boots, and M. C. M. de Jong. 2018. Digital dermatitis in dairy cattle: The contribution of different disease classes to transmission. Epidemics 23:76-84. https://doi .org/10.1016/j.epidem.2017.12.007.

Bjerg, B. S., and I. C. Klaas. 2014. Water and ammonia evaporation in a compost bedded pack dairy barn with under floor aeration. Presentation 141899106 at ASABE/CSBE/ASABE Joint Meeting. American Society of Agricultural and Biological Engineers, St. Joseph, MI.

Black, R. A., J. L. Taraba, G. B. Day, F. A. Damasceno, and J. M. Bewley. 2013. Compost bedded pack dairy barn management, performance, and producer satisfaction. J. Dairy Sci. 96:8060-8074. https://doi.org/10.3168/jds.2013-6778.

Black, R. A., J. L. Taraba, G. B. Day, F. A. Damasceno, M. C. Newman, K. A. Akers, C. L. Wood, K. J. McQuerry, and J. M. Bewley. 2014. The relationship between compost bedded pack performance, management, and bacterial counts. J. Dairy Sci. 97:2669-2679. https://doi.org/10.3168/jds.2013-6779.

Borchers, M. R. 2018. The effects of housing on dairy cow comfort, immune function, stress, productivity, and milk quality. PhD Dissertation. University of Kentucky, Lexington, KY.

Brito, E. C. 2016. Produção intensiva de leite em compost barn: Uma avaliação técnica e econômica sobre a sua viabilidade. MS Thesis. Federal University of Juiz de Fora, Juiz de Fora, Brazil.

Burgstaller, J., J. Raith, S. Kuchling, V. Mandl, A. Hund, and J. Kofler. 2016. Claw health and prevalence of lameness in cows from compost bedded and cubicle freestall dairy barns in Austria. Vet. J. 216:81-86. https://doi.org/10.1016/j.tvjl.2016.07.006.

Cook, N. B., T. B. Bennett, and K. V. Nordlund. 2004. Effect of free stall surface on daily activity patterns in dairy cows with relevance to lameness prevalence. J. Dairy Sci. 87:2912-2922. https://doi .org/10.3168/jds.S0022-0302(04)73422-0.

Cook, N. B., J. P. Hess, M. R. Foy, T. B. Bennett, and R. L. Brotzman. 2016. Management characteristics, lameness, and body injuries of dairy cattle housed in high-performance dairy herds in Wisconsin. J. Dairy Sci. 99:5879-5891. https://doi.org/10.3168/jds.2016 -10956 .

Costa, J. H. C., T. A. Burnett, M. A. G. von Keyserlingk, and M. J. Hötzel. 2018. Prevalence of lameness and leg lesions of lactating dairy cows housed in southern Brazil: Effects of housing systems. J. Dairy Sci. 101:2395-2405. https://doi.org/10.3168/jds.2017 $-13462$.

Damasceno, F. A. 2012. Compost bedded pack barns system and computational simulation of airflow through naturally ventilated reduced model. PhD Thesis. Federal University of Viçosa, Viçosa, Brazil.

de Boer, H. 2014. On farm development of bedded pack dairy barns in The Netherlands - Nutrient balances and manure quality of bedding material. Report 709. Wageningen UR Livestock Research, Lelystad, the Netherlands.

Dippel, S., M. Dolezal, C. Brenninkmeyer, J. Brinkmann, S. March, U. Knierim, and C. Winckler. 2009. Risk factors for lameness in freestall-housed dairy cows across two breeds, farming systems, and countries. J. Dairy Sci. 92:5476-5486. https://doi.org/10 $.3168 /$ jds.2009-2288.

Driehuis, F., E. Lucas-van den Bos, and M. H. J. Wells-Bennik. 2012. Risks of microbial contaminants of bedding materials: Compost, cattle manure solids, horse dung and bedded pack barns. Nizo report 2012/119. Nizo, Ede, the Netherlands.

Driehuis, F., E. Lucas-van den Bos, and M. H. J. Wells-Bennik. 2014. Spores of thermophilic aerobic sporeformers in compost and other bedding materials used by dairy farms with a bedded pack or freestall barn. Nizo report 2014/045. Nizo, Ede, the Netherlands.

Eckelkamp, E. A., C. N. Gravatte, C. O. Coombs, and J. M. Bewley. 2014. Case study: Characterization of lying behavior in dairy cows transitioning from a freestall barn with pasture access to a compost bedded pack barn without pasture access. Prof. Anim. Sci. 30:109-113. https://doi.org/10.15232/S1080-7446(15)30092-9.

Eckelkamp, E. A., J. L. Taraba, K. A. Akers, R. J. Harmon, and J. M. Bewley. 2016a. Understanding compost bedded pack barns: Interactions among environmental factors, bedding characteristics, and udder health. Livest. Sci. 190:35-42. https://doi.org/10.1016/ j.livsci.2016.05.017. 
Eckelkamp, E. A., J. L. Taraba, K. A. Akers, R. J. Harmon, and J. M. Bewley. 2016b. Sand bedded freestall and compost bedded pack effects on cow hygiene, locomotion, and mastitis indicators. Livest. Sci. 190:48-57. https://doi.org/10.1016/j.livsci.2016.06.004.

Eicher, S. D., D. C. Lay Jr., J. D. Arthington, and M. M. Schutz. 2013. Effects of rubber flooring during the first 2 lactations on production, locomotion, hoof health, immune functions, and stress. J. Dairy Sci. 96:3639-3651. https://doi.org/10.3168/jds.2012-6049.

Endres, M. I., and A. E. Barberg. 2007. Behavior of dairy cows in an alternative bedded-pack housing system. J. Dairy Sci. 90:41924200. https://doi.org/10.3168/jds.2006-751.

EFSA (European Food Safety Authority). 2009. Scientific report of EFSA prepared by the Animal Health and Animal Welfare Unit on the effects of farming systems on dairy cow welfare and disease. EFSA J. 1143:1-284. https://doi.org/10.2903/j.efsa.2009.1143r.

Evans, J. T., M. P. Sama, J. L. Taraba, and G. B. Day. 2017. Automated calibration of electrochemical oxygen sensors for use in compost bedded pack barns. Trans. ASABE 60:957-962. https:// doi.org/10.13031/trans.12099.

Fabian-Wheeler, E. E., M. L. Hile, D. J. Murphy, D. E. Hill, R. Meinen, R. C. Brandt, H. A. Elliott, and D. Hofstetter. 2017. Operator exposure to hydrogen sulfide from dairy manure storages containing gypsum bedding. J. Agric. Saf. Health 23:9-22. https://doi .org/10.13031/jash.11563.

FAO (Food and Agriculture Organization of the United Nations). 2003. On-farm composting methods. Land and water discussion paper 2 . FAO, Rome, Italy.

Fávero, S., F. V. R. Portilho, A. C. R. Oliveira, H. Langoni, and J. C. F. Pantoja. 2015a. Factors associated with mastitis epidemiologic indexes, animal hygiene, and bulk milk bacterial concentrations in dairy herds housed on compost bedding. Livest. Sci. 181:220-230. https://doi.org/10.1016/j.livsci.2015.09.002.

Fávero, S., F. V. R. Portilho, A. C. R. Oliveira, H. Langoni, and J. C. F. Pantoja. 2015b. Longitudinal trends and associations between compost bedding characteristics and bedding bacterial concentrations. J. Agric. Sci. 7:58-70. https://doi.org/10.5539/jas .v7n10p58.

Faye, B., and J. Barnouin. 1985. Objectivation de la propreté des vaches laitières et des stabulations - L'indice de propreté. Bulletin Technique CRZV Theix 59:61-67.

Fetrow, J., K. V. Nordlund, and H. D. Norman. 2006. Invited review: Culling: Nomenclature, definitions, and recommendations. J. Dairy Sci. 89:1896-1905. https://doi.org/10.3168/jds.S0022 -0302(06)72257-3.

Fjeldaas, T., A. M. Sogstad, and O. Østerås. 2011. Locomotion and claw disorders in Norwegian dairy cows housed in freestalls with slatted concrete, solid concrete, or solid rubber flooring in the alleys. J. Dairy Sci. 94:1243-1255. https://doi.org/10.3168/jds.2010 -3173 .

Flower, F. C., and D. M. Weary. 2006. Effect of hoof pathologies on subjective assessments of dairy cow gait. J. Dairy Sci. 89:139-146. https://doi.org/10.3168/jds.S0022-0302(06)72077-X.

Frankena, K., J. G. C. J. Somers, W. G. P. Schouten, J. V. van Stek, J. H. M. Metz, E. N. Stassen, and E. A. M. Graat. 2009. The effect of digital lesions and floor type on locomotion score in Dutch dairy cows. Prev. Vet. Med. 88:150-157. https://doi.org/10.1016/ j.prevetmed.2008.08.004.

Fregonesi, J. A., and J. D. Leaver. 2001. Behaviour, performance and health indicators of welfare for dairy cows housed in strawyard or cubicle systems. Livest. Prod. Sci. 68:205-216. https://doi.org/10 1016/S0301-6226(00)00234-7.

Fregonesi, J. A., D. M. Veira, M. A. G. von Keyserlingk, and D. M. Weary. 2007. Effects of bedding quality on lying behavior of dairy cows. J. Dairy Sci. 90:5468-5472. https://doi.org/10.3168/jds.2007 -0494 .

Fregonesi, J. A., M. A. G. von Keyserlingk, C. B. Tucker, D. M. Veira, and D. M. Weary. 2009. Neck-rail position in the free stall affects standing behavior and udder and stall cleanliness. J. Dairy Sci. 92:1979-1985. https://doi.org/10.3168/jds.2008-1604.

Fulwider, W. K., T. Grandin, D. J. Garrick, T. E. Engle, W. D. Lamm, N. L. Dalsted, and B. E. Rollin. 2007. Influence of free-stall base on tarsal joint lesions and hygiene in dairy cows. J. Dairy Sci. 90:3559-3566. https://doi.org/10.3168/jds.2006-793.

Galama, P. J. 2014. On farm development of bedded pack dairy barns in the Netherlands. Report 707. Wageningen UR Livestock Research, Lelystad, the Netherlands.

Galama, P. J., S. Bokma, H. J. van Dooren, W. Ouweltjes, M. Smits, and F. Driehuis. 2011. Prospects for bedded pack barns for dairy cattle. Wageningen UR Livestock Research, Lelystad, the Netherlands.

Galama, P. J., H. de Boer, H. J. van Dooren, W. Ouweltjes, J. Poelarends, S. Bokma, and F. Driehuis. 2014. Vrijloopstallen voor melkvee in de praktijk. Wageningen UR Livestock Research, Lelystad, the Netherlands.

Galama, P. J., H. C. de Boer, H. J. C. van Dooren, W. Ouweltjes, and F. Driehuis. 2015. Sustainable aspects of ten bedded pack barns in the Netherlands. Report 873. Wageningen UR Livestock Research, Lelystad, the Netherlands.

Ghielmetti, G., S. Corti, U. Friedel, E. Hübschke, C. Feusi, and R. Stephan. 2017. Mastitis associated with Mycobacterium smegmatis complex members in a Swiss dairy cattle herd: Compost bedding material as a possible risk factor. Schweiz. Arch. Tierheilkd. 159:673-676. https://doi.org/10.17236/sat00140.

Gomez, A., and N. B. Cook. 2010. Time budgets of lactating dairy cattle in commercial freestall herds. J. Dairy Sci. 93:5772-5781. https://doi.org/10.3168/jds.2010-3436.

Gooch, C. 2008. Dairy freestall barn design-A Northeast perspective. Pages 1-12 in 9th Annual Fall Dairy Conference. Cornell University College of Veterinary Medicine and Cornell PRO-DAIRY Program, Ithaca, NY.

Hadley, G. L., C. A. Wolf, and S. B. Harsh. 2006. Dairy cattle culling patterns, explanations, and implications. J. Dairy Sci. 89:22862296. https://doi.org/10.3168/jds.S0022-0302(06)72300-1.

Haley, D. B., A. M. de Passillé, and J. Rushen. 2001. Assessing cow comfort: Effects of two floor types and two tie stall designs on the behaviour of lactating dairy cows. Appl. Anim. Behav. Sci. 71:105-117. https://doi.org/10.1016/S0168-1591(00)00175-1.

Haskell, M. J., L. J. Rennie, V. A. Bowell, M. J. Bell, and A. B. Lawrence. 2006. Housing system, milk production, and zero-grazing effects on lameness and leg injury in dairy cows. J. Dairy Sci. 89:4259-4266. https://doi.org/10.3168/jds.S0022-0302(06)72472 $-9$.

Janni, K. A., M. I. Endres, J. K. Reneau, and W. W. Schoper. 2007. Compost dairy barn layout and management recommendations. Appl. Eng. Agric. 23:97-102. https://doi.org/10.13031/2013 22333.

Jasper, D. E. 1980. The coliform mastitis enigma: Cows, sawdust, softwood shavings, bedding. Pages 23-34 in Proc. Int. Congr. Dis. Cattle, Tel Aviv, Israel. Bregman Press, Haifa, Israel.

Jeppsson, K. H. 1999. Volatilization of ammonia in deep-litter systems with different bedding materials for young cattle. J. Agric. Eng. Res. 73:49-57. https://doi.org/10.1006/jaer.1998.0387.

Jewell, M. T., M. Cameron, J. Spears, S. L. McKenna, M. S. Cockram, J. Sanchez, and G. P. Keefe. 2019. Prevalence of lameness and associated risk factors on dairy farms in the Maritime Provinces of Canada. J. Dairy Sci. 102:3392-3405. https://doi.org/10.3168/jds .2018-15349

Kanters, J. 2018. Design for deconstruction in the design process: State of the art. Buildings 8:150. https://doi.org/10.3390/ buildings 8110150 .

Kester, E., M. Holzhauer, and K. Frankena. 2014. A descriptive review of the prevalence and risk factors of hock lesions in dairy cows. Vet. J. 202:222-228. https://doi.org/10.1016/j.tvj1.2014.07.004.

Klaas, I. C., B. S. Bjerg, S. Friedmann, and D. Bar. 2010. Cultivated barns for dairy cows: An option to promote cattle welfare and environmental protection in Denmark? Dansk Vettidsskr. 93:20-29.

LeBlanc, L., and D. Anderson. 2013. Waste Wallboard and Wood Fiber for Use as an Alternative Dairy Bedding Material. LP Consulting Ltd., Mount Uniacke, NS, Canada.

Leonard, J. 2001. Composting, an alternative approach to manure management. Adv. Dairy Technol. 13:431-441. 
Leso, L. 2015. Performance and design of an alternative housing system for dairy cows. PhD Thesis. University of Florence, Florence, Italy.

Leso, L., L. Conti, G. Rossi, and M. Barbari. 2018. Criteria of design for deconstruction applied to dairy cows housing: A case study in Italy. Agron. Res. (Tartu) 16:794-805. https://doi.org/10.15159/ ar.18.085.

Leso, L., W. Morshed, L. Conti, and M. Barbari. 2017. Evaluating thermal performance of experimental building solutions designed for livestock housing: The effect of greenery systems. Agron. Res. (Tartu) 15:239-248.

Leso, L., P. Pellegrini, and M. Barbari. 2019. Effect of two housing systems on performance and longevity of dairy cows in Northern Italy. Agron. Res. (Tartu) 17:574-581. https://doi.org/10.15159/ ar.19.107.

Leso, L., M. Uberti, W. Morshed, and M. Barbari. 2013. A survey of Italian compost dairy barns. J. Agric. Eng. XLIV(e17):120-124. https://doi.org/10.4081/jae.2013.282.

Lobeck, K. M., M. I. Endres, K. A. Janni, S. M. Godden, and J. Fetrow. 2012. Environmental characteristics and bacterial counts in bedding and milk bulk tank of low profile cross-ventilated, naturally ventilated, and compost bedded pack dairy barns. Appl. Eng. Agric. 28:117-128. https://doi.org/10.13031/2013.41280.

Lobeck, K. M., M. I. Endres, E. M. Shane, S. M. Godden, and J. Fetrow. 2011. Animal welfare in cross-ventilated, compost-bedded pack, and naturally ventilated dairy barns in the upper Midwest. J. Dairy Sci. 94:5469-5479. https://doi.org/10.3168/jds.2011-4363.

Lombard, J. E., C. B. Tucker, M. A. G. von Keyserlingk, C. A. Kopral, and D. M. Weary. 2010. Associations between cow hygiene, hock injuries, and free stall usage on US dairy farms. J. Dairy Sci. 93:4668-4676. https://doi.org/10.3168/jds.2010-3225.

Lopes, M. A., F. de Moraes, F. M. Carvalho, A. C. C. Peres, F. R. P. Bruhn, and E. M. B. Reis. 2015. The effect of technological levels on profits of milk production systems participating in the "full bucket" program: A multicase study. Semin. Cienc. Agrar. 36:29092922. https://doi.org/10.5433/1679-0359.2015v36n4p2909.

López-Gatius, F. 2012. Factors of a noninfectious nature affecting fertility after artificial insemination in lactating dairy cows. A review. Theriogenology 77:1029-1041. https://doi.org/10.1016/j .theriogenology.2011.10.014.

López-Gatius, F., P. Santolaria, I. Mundet, and J. L. Yániz. 2005. Walking activity at estrus and subsequent fertility in dairy cows. Theriogenology 63:1419-1429. https://doi.org/10.1016/j .theriogenology.2004.07.007.

Maia, G. D., G. B. Day, R. S. Gates, J. L. Taraba, and M. S. Coyne. 2012. Moisture effects on greenhouse gases generation in nitrifying gas-phase compost biofilters. Water Res. 46:3023-3031. https:// doi.org/10.1016/j.watres.2012.03.007.

Mota, V. C., A. T. Campos, F. A. Damasceno, E. A. M. Resende, C. P. A. Rezende, L. R. A. Abreu, and T. Vareiro. 2017. Confinamento para bovinos leiteiros: Histórico e características. Pubvet 11:433-442. https://doi.org/10.22256/pubvet.v11n5.433-442.

Mota, V. C., F. A. Damasceno, and D. F. Leite. 2018. Fuzzy clustering and fuzzy validity measures for knowledge discovery and decision making in agricultural engineering. Comput. Electron. Agric. 150:118-124. https://doi.org/10.1016/j.compag.2018.04.011.

Nocek, J. 2010. Hock Assessment Chart for Cattle. Cornell Cooperative Extension, Ithaca, NY.

Norring, M., E. Manninen, A. M. de Passillé, J. Rushen, L. Munksgaard, and H. Saloniemi. 2008. Effects of sand and straw bedding on the lying behavior, cleanliness, and hoof and hock injuries of dairy cows. J. Dairy Sci. 91:570-576. https://doi.org/10.3168/jds 2007-0452.

NRCS (Natural Resources Conservation Service). 1999. Agricultural waste management field handbook. Part 651. USDA, Washington, DC.

Ofner-Schröck, E., M. Zähner, G. Huber, K. Guldimann, T. Guggenberger, and J. Gasteiner. 2015. Compost barns for dairy cows-Aspects of animal welfare. Open J. Anim. Sci. 5:124-131. https://doi .org/10.4236/ojas.2015.52015.
Ouweltjes, W., and G. Smolders. 2014. On farm development of bedded pack dairy barns in the Netherlands-Animal welfare and milk quality. Report 708. Wageningen UR Livestock Research, Lelystad, the Netherlands.

Peeler, E. J., M. J. Green, J. L. Fitzpatrick, K. L. Morgan, and L. E. Green. 2000. Risk factors associated with clinical mastitis in low somatic cell count British dairy herds. J. Dairy Sci. 83:2464-2472. https://doi.org/10.3168/jds.S0022-0302(00)75138-1.

Petersen, S. O. 2018. Greenhouse gas emissions from liquid dairy manure: Prediction and mitigation. J. Dairy Sci. 101:6642-6654. https://doi.org/10.3168/jds.2017-13301.

Petzen, J., C. Wolfanger, J. Bonhotal, M. Schwarz, T. Terry, and N. Youngers. 2009. Case study: Eagleview compost dairy barn. Cornell Cooperative Extension of Wyoming County, Warsaw, NY.

Pilatti, J. A., F. M. C. Vieira, F. Rankrape, and E. S. Vismara 2019. Diurnal behaviors and herd characteristics of dairy cows housed in a compost-bedded pack barn system under hot and humid conditions. Animal 13:399-406. https://doi.org/10.1017/ S1751731118001088.

Platz, S., F. Ahrens, E. Bahrs, S. Nuske, and M. H. Erhard. 2007. Association between floor type and behaviour, skin lesions, and claw dimensions in group-housed fattening bulls. Prev. Vet. Med. 80:209-221. https://doi.org/10.1016/j.prevetmed.2007.02.007.

Platz, S., F. Ahrens, J. Bendel, H. H. D. Meyer, and M. H. Erhard. 2008. What happens with cow behavior when replacing concrete slatted floor by rubber coating: A case study. J. Dairy Sci. 91:9991004. https://doi.org/10.3168/jds.2007-0584.

Reneau, J. K., A. J. Seykora, B. J. Heins, M. I. Endres, R. J. Farnsworth, and R. F. Bey. 2005. Association between hygiene scores and somatic cell scores in dairy cattle. J. Am. Vet. Med. Assoc. 227:1297-1301. https://doi.org/10.2460/javma.2005.227.1297.

Rosen, C., T. R. Halback, and R. Mugaas. 2000. Composting and mulching: A guide to managing organic yard waste. University of Minnesota Extension publication no. BU-3296-GO. University of Minnesota, St. Paul, MN.

Rynk, R., M. van de Kamp, G. B. Willson, M. E. Singley, T. L. Richard, J. J. Kolega, F. R. Gouin, L. Laliberty Jr., D. Kay, D. W. Murphy, H. A. J. Hoitink, and W. F. Brinton. 1992. On-Farm Composting Handbook. Northeast Regional Agricultural Engineering Service, Ithaca, NY.

Saishu, N., K. Morimoto, H. Yamasato, H. Ozaki, and T. Murase. 2015. Characterization of Aerococcus viridans isolated from milk samples from cows with mastitis and manure samples. J. Vet. Med. Sci. 77:1037-1042. https://doi.org/10.1292/jvms.15-0100.

Schirmann, K., N. Chapinal, D. M. Weary, W. Heuwieser, and M. A. G. von Keyserlingk. 2012. Rumination and its relationship to feeding and lying behavior in Holstein dairy cows. J. Dairy Sci. 95:3212-3217. https://doi.org/10.3168/jds.2011-4741.

Shane, E. M., M. I. Endres, D. G. Johnson, and J. K. Reneau. 2010 Bedding options for an alternative housing system for dairy cows: A descriptive study. Appl. Eng. Agric. 26:659-666. https://doi .org/10.13031/2013.32062.

Silva, G. R., M. A. Lopes, A. L. R. Lima, G. M. Costa, F. A. Damasceno, V. P. Barros, and M. Barbari. 2019. Profitability analysis of compost barn and free stall milk-production systems: A comparison. Semin. Cienc. Agrar. 40:1165-1184. https://doi.org/10.5433/ 1679-0359.2019v40n3p1165.

Smits, M. C. J., and A. J. A. Aarnink. 2009. Verdampinguitligbodems van vrijloopstallen; oriënterendemodelberekeningen. Report 230. Wageningen UR Livestock Research, Lelystad, the Netherlands.

Somers, J. G. C. J., K. Frankena, E. N. Noordhuizen-Stassen, and J. H. M. Metz. 2003. Prevalence of claw disorders in Dutch dairy cows exposed to several floor systems. J. Dairy Sci. 86:2082-2093. https://doi.org/10.3168/jds.S0022-0302(03)73797-7.

Somers, J. G. C. J., W. G. P. Schouten, K. Frankena, E. N. Noordhuizen-Stassen, and J. H. M. Metz. 2005. Development of claw traits and claw lesions in dairy cows kept on different floor systems. J. Dairy Sci. 88:110-120. https://doi.org/10.3168/jds.S0022 $-0302(05) 72668-0$

Stentiford, E. I. 1996. Composting control: Principles and practice. Pages 49-59 in The Science of Composting. M. de Bertoldi, P. 
Sequi, B. Lemmes, and T Papi, ed. Springer, Dordrecht, the Netherlands.

Svennesen, L., C. Enevoldsen, B. S. Bjerg, and I. C. Klaas. 2014. Udder health in a Danish compost bedded pack barn. Abstract presented at NMC Regional Meeting, Ghent, Belgium.

Telezhenko, E., and C. Bergsten. 2005. Influence of floor type on the locomotion of dairy cows. Appl. Anim. Behav. Sci. 93:183-197. https://doi.org/10.1016/j.applanim.2004.11.021.

Telezhenko, E., C. Bergsten, M. Magnusson, and C. Nilsson. 2009. Effect of different flooring systems on claw conformation of dairy cows. J. Dairy Sci. 92:2625-2633. https://doi.org/10.3168/jds.2008 -1798 .

Tomazi, T., F. M. Coura, J. L. Gonçalves, M. B. Heinemann, and M. V. Santos. 2018. Antimicrobial susceptibility patterns of Escherichia coli phylogenetic groups isolated from bovine clinical mastitis. J. Dairy Sci. 101:9406-9418. https://doi.org/10.3168/jds.2018 -14485 .

Tucker, C. B., D. M. Weary, and D. Fraser. 2005. Influence of neckrail placement on free-stall preference, use, and cleanliness. J. Dairy Sci. 88:2730-2737. https://doi.org/10.3168/jds.S0022 -0302(05)72952-0.

van Dooren, H. J., P. J. Galama, M. C. J. Smits, W. Ouweltjes, F Driehuis, and S. Bokma. 2011. Bodemsvoorvrijloopstallen. Report 411. Wageningen UR Livestock Research, Lelystad, the Netherlands.

van Dooren, H. J. C., J. M. G. Hol, K. Blanken, and P. J. Galama. 2019. Gasvormige emissies uit vrijloopstallen met houtsnipperbodems; Ammoniak-, lachgas- en methaanemissie op stalniveau. Report 1163. Wageningen UR Livestock Research, Lelystad, the Netherlands.

Vanegas, J., M. Overton, S. L. Berry, and W. M. Sischo. 2006. Effect of rubber flooring on claw health in lactating dairy cows housed in free-stall barns. J. Dairy Sci. 89:4251-4258. https://doi.org/10 .3168/jds.S0022-0302(06)72471-7. von Keyserlingk, M. A. G., A. Barrientos, K. Ito, E. Galo, and D. M. Weary. 2012. Benchmarking cow comfort on North American freestall dairies: Lameness, leg injuries, lying time, facility design, and management for high-producing Holstein dairy cows. J. Dairy Sci. 95:7399-7408. https://doi.org/10.3168/jds.2012-5807.

Wagner, P. E. 2002. Bedded pack shelters. Lancaster Farming 47:36.

Webster, J. 1995. Animal Welfare: A Cool Eye Towards Eden: A Constructive Approach to the Problem of Man's Domination over Animals. Blackwell Science, Oxford, UK.

Weigel, K. A., R. W. Palmer, and D. Z. Caraviello. 2003. Investigation of factors affecting voluntary and involuntary culling in expanding dairy herds in Wisconsin using survival analysis. J. Dairy Sci. 86:1482-1486. https://doi.org/10.3168/jds.S0022-0302(03)73733 $-3$.

https://doi.org/Wolf, K. 2017. A portable sensor for measuring gas emissions from dairy compost bedded pack barns. MS Thesis. University of Kentucky, Lexington, KY.

Woodford, K., A. Roberts, and M. Manning. 2018. Dairy composting barns can improve productivity, enhance cow welfare and reduce environmental footprint: A synthesis of current knowledge and research needs. Pages 1-6 in Farm Environmental Planning-Science, Policy and Practice. L. D. Currie and C. L. Christensen, ed. Occasional report no. 31. Fertilizer and Lime Research Centre, Massey University, Palmerston North, New Zealand.

\section{ORCIDS}

L. Leso ำ https://orcid.org/0000-0003-4274-3921

M. Barbari ๑ https://orcid.org/0000-0002-0760-8604

P. Galama ๑ https://orcid.org/0000-0001-9514-678X

A. Kuipers (ํ) https://orcid.org/0000-0001-7301-943X 